\title{
Blood Stream Infections from MDR Bacteria
}

\author{
Sveva Di Franco ${ }^{1}{ }^{\oplus}$, Aniello Alfieri ${ }^{1}{ }^{\oplus}$, Maria Caterina Pace ${ }^{1}$, Pasquale Sansone ${ }^{1}{ }^{\oplus}$, Vincenzo Pota ${ }^{1}{ }^{\circledR}$, \\ Ciro Fittipaldi ${ }^{2}$, Marco Fiore ${ }^{1}\left[\right.$ and Maria Beatrice Passavanti ${ }^{1, * \mathbb{C}}$
}

1 Department of Women, Child and General and Specialized Surgery, University of Campania "Luigi Vanvitelli", 80138 Naples, Italy; svevadifranco@gmail.com (S.D.F.); anielloalfieri@gmail.com (A.A.); caterina.pace@libero.it (M.C.P.); pasquale.sansone@unicampania.it (P.S.); vincenzo.pota@unicampania.it (V.P.); marco.fiore@unicampania.it (M.F.)

2 Unit of Critical Care Hospital “Ospedale Pellegrini”, 80138 Naples, Italy; cirofittipaldi@virgilio.it

* Correspondence: MariaBeatrice.PASSAVANTI@unicampania.it; Tel.: +39-081-566-5180

Citation: Di Franco, S.; Alfieri, A.; Pace, M.C.; Sansone, P.; Pota, V.; Fittipaldi, C.; Fiore, M.; Passavanti, M.B. Blood Stream Infections from MDR Bacteria. Life 2021, 11, 575. https://doi.org/10.3390/life11060575

Academic Editor: Milan Kolář

Received: 9 May 2021

Accepted: 14 June 2021

Published: 18 June 2021

Publisher's Note: MDPI stays neutral with regard to jurisdictional claims in published maps and institutional affiliations.

Copyright: (C) 2021 by the authors. Licensee MDPI, Basel, Switzerland. This article is an open access article distributed under the terms and conditions of the Creative Commons Attribution (CC BY) license (https:// creativecommons.org/licenses/by/ $4.0 /)$.

\begin{abstract}
Background: Bloodstream infections (BSIs) constitute a growing public health concern, are among the most severe nosocomial pathologies, and are considered a worldwide cause of unfaithful outcomes, increasing treatment costs and diagnostic uncertainties. BSIs are one of the most frequent lethal conditions that are managed in intensive care units (ICUs). In the case of septic shock, immune deficiency, and delayed treatment, even with adequate antimicrobial therapy and/or source control, the outcomes are often unfavorable. Methods: this review article summarizes the epidemiological and microbiological characteristics of BSIs with a particular focus on ICU acquired BSIs (ICU-BSIs), which are usually caused by multidrug-resistant (MDR) pathogens. For this reason, their antimicrobial resistance patterns and therapeutic options have also been compiled. Results: ICU-acquired BSIs prevail in 5-7\% of ICU patients. Klebsiella pneumoniae, Escherichia coli, Acinetobacter baumannii, and Pseudomonas aeruginosae are the pathogens most often responsible for MDR infections. MDR Enterobacteriaceae have seen their prevalence increase from $6.2 \%$ (1997-2000) to 15.8\% (2013-2016) in recent years. Conclusions: Considering that prevention and treatment of sepsis is nowadays considered a global health priority by the World Health Organization, it is our obligation to invest more resources into solving or reducing the spread of these unfaithful infections. It is relevant to identify patients with risk factors that make them more susceptible to BSIs, to guarantee earlier molecular or microbiological diagnoses, and more rapidly appropriate treatment by using de-escalation strategies where possible.
\end{abstract}

Keywords: bloodstream infections; intensive care unit; multidrug-resistant pathogens; septic shock

\section{Introduction}

This review article summarizes the epidemiological and microbiological characteristics of bloodstream infections (BSIs) with a particular focus on intensive care unit (ICU) acquired BSIs (ICU-BSIs) caused by multidrug-resistant (MDR) pathogens, the development of resistance to antimicrobial drugs, and therapeutic strategies for empirical and targeted therapy of MDR BSIs.

BSIs are defined by positive blood culture or cultures (with an isolate of the same species grown in at least one blood culture bottle) in a patient with systemic signs of infection (i.e., a patient who has evidence of one or more of the symptoms or signs, which are fever (body temperature $>38^{\circ} \mathrm{C}$ ), hypothermia (body temperature $<36{ }^{\circ} \mathrm{C}$ ), chills, hypotension, oliguria, or high lactate levels) [1].

BSIs constitute a growing public health concern, a life-threatening nosocomial pathology, and a worldwide primary cause of morbidity and mortality, increasing treatment costs and diagnostic uncertainties [2].

Mortality associated with BSI is $14 \%$ for BSIs developed in the community, while the rate grows to $30 \%$ in case of patients with severe comorbidities (i.e., cirrhosis, oncohematologic diseases, or solid-organ transplants) [3-5]. 
In the case of critically ill patients, due to their high predisposition to BSIs, in the first month of hospitalization in ICUs a 7\% incidence of BSIs has been reported [6].

Among this specific patient population, BSIs caused by multidrug-resistant (MDR) bacteria are a worrisome phenomenon because if they are not adequately and promptly treated, these infections are correlated with prolonged ICU stays, high costs, and poor outcomes [7].

The mortality rates are between $40 \%$ and $60 \%$, increasing the risk of hospital death due to organ dysfunction such as sepsis or septic shock by three times. [6]

Considering that sepsis has recently been included in the global health priorities by the World Health Organization, it is our obligation to prevent this severe and unfaithful clinical evolution of BSIs [8].

\section{Methodology}

We conducted a comprehensive literature search involving several databases including PubMed, Embase, and Cochrane Library. The search terms included a combination of keywords and medical subject heading $(\mathrm{MeSH})$ terms. More information on the strings used are available in Appendix A.

We followed a selection process to identify the most informative studies, analyzing titles and abstracts to retain relevant manuscripts. The full texts of the relevant manuscripts were analyzed to extract information about antibiotic resistance in bloodstream infections. Epidemiological data were obtained using Sentry Program datasets. The results of several database queries were merged and analyzed through Microsoft Excel (ver. 2019).

\section{Epidemiology}

The epidemiology of BSIs is complex, since ICU-BSIs present unique epidemiologic characteristics when compared with the BSIs that complicate both community-acquired(CA) and hospital-acquired-(HA) infections [9].

The uniqueness of the epidemiology of BSIs, even those caused by MDR pathogens, is related to numerous factors. A mixture of different ICUs, geographical locations, antimicrobial management approaches, and the applied policies of infection control influence a BSI's characteristics.

Worldwide, in the range of $5-7 \%$ of ICU admissions are reported to have developed a BSI there. This corresponds to a mean of 6-10 episodes per 1000 patient-days [2].

HA-BSIs in critically ill patients are community imported (i.e., documented at ICU admission) in $25 \%$ of cases, while most HA-BSI cases $(75 \%)$ are acquired after admittance to the ICU $[10,11]$.

Table 1 synthesizes the prevalence of BSIs recently reported on the SENTRY database, describing the prevalence of each pathogen in different geographical regions.

Among the pathogens causing BSIs reported in Table 1, listed in order of prevalence, we found in the first positions K. pneumoniae and E. coli with 1882 and 1747 cases of BSIs, respectively, followed by the $A$. baumannii calcoaceticus species complex and $P$. aeruginosae with 855 and 612 cases of BSIs, respectively. Proteus mirabilis was isolated among 315 cases, E. cloacae species complex in 180 cases, and S. marcescens in 124 cases.

According to geographical distribution in West Europe, North America, and Asia, the major prevalence is for E. coli BSIs, while in East Europe and South America the leader is K. pneumoniae.

Comparing the data reported in Table 1 with the data collected prior to 2008, the epidemiological trend of BSIs has dramatically changed. Between 1997 and 2004, the most common pathogen overall was $S$. aureus. Furthermore, from 2005 the prevalence of $S$. aureus resistant to methicillin (MRSA) or oxacillin (ORSA) grew until 2008 before declining from that year among community settings in all geographical regions [1]. 
Table 1. Number of reported cases of BSIs according to pathogens and geographical distribution.

\begin{tabular}{|c|c|c|c|c|c|c|}
\hline \multirow[t]{2}{*}{$\begin{array}{l}\text { Pathogens } \\
\text { Causing BSIs }\end{array}$} & \multicolumn{6}{|c|}{ Reported Cases of BSIs for Country ( $n=$ Number of Cases) } \\
\hline & $\begin{array}{c}\text { World } \\
\text { n. BSIs/n. Tot } \\
(66,729 / 319,581)\end{array}$ & $\begin{array}{c}\text { Asia } \\
\text { n. BSIs/n. Tot } \\
(6914 / 29,359)\end{array}$ & $\begin{array}{l}\text { West Europe } \\
\text { n. BSIs/n. Tot } \\
(20,897 / 77,554)\end{array}$ & $\begin{array}{c}\text { East Europe } \\
\text { n. BSIs/n. Tot } \\
(6689 / 29,313)\end{array}$ & $\begin{array}{c}\text { South America } \\
\text { n. BSIs/n. Tot } \\
(5188 / 19,462)\end{array}$ & $\begin{array}{c}\text { North America } \\
\text { n. BSIs/n. Tot } \\
(27,041 / 163,893)\end{array}$ \\
\hline K. pneumoniae & 1882 & 150 & 551 & 561 & 335 & 285 \\
\hline $\begin{array}{c}\text { Escherichia } \\
\text { coli }\end{array}$ & 1747 & 266 & 612 & 285 & 164 & 420 \\
\hline $\begin{array}{c}\text { Acinetobacter } \\
\text { baumannii- } \\
\text { calcoaceticus } \\
\text { species complex }\end{array}$ & 855 & 98 & 188 & 345 & 155 & 69 \\
\hline $\begin{array}{l}\text { Pseudomonas } \\
\text { aeruginosae }\end{array}$ & 612 & 41 & 172 & 175 & 75 & 149 \\
\hline $\begin{array}{l}\text { Proteus } \\
\text { mirabilis }\end{array}$ & 351 & 13 & 142 & 50 & 14 & 132 \\
\hline $\begin{array}{c}\text { E. cloacae } \\
\text { species complex }\end{array}$ & 180 & 22 & 22 & 18 & 48 & 70 \\
\hline S. marcescens & 124 & 2 & 33 & 34 & 32 & 23 \\
\hline E. cloacae & 114 & 12 & 44 & 23 & 14 & 21 \\
\hline $\begin{array}{c}\text { Morganella } \\
\text { morganii }\end{array}$ & 87 & 3 & 23 & 10 & 6 & 45 \\
\hline K. oxytoca & 59 & 1 & 21 & 8 & 8 & 21 \\
\hline P. stuartii & 54 & & 12 & 9 & 4 & 29 \\
\hline $\begin{array}{l}\text { Klebsiella } \\
\text { aerogenes }\end{array}$ & 41 & 5 & 15 & 5 & 3 & 13 \\
\hline $\begin{array}{c}\text { C. freundii } \\
\text { species complex }\end{array}$ & 25 & 3 & 8 & 1 & 1 & 12 \\
\hline $\begin{array}{l}\text { Citrobacter } \\
\text { freundii }\end{array}$ & 14 & & 7 & & & 7 \\
\hline Hafnia alvei & 14 & & 9 & 1 & & 4 \\
\hline A. lwoffii & 7 & & & 2 & 2 & 3 \\
\hline A. pittii & 7 & 1 & 2 & 2 & & 2 \\
\hline $\begin{array}{l}\text { Providencia } \\
\text { rettgeri }\end{array}$ & 5 & & & & 1 & 4 \\
\hline $\begin{array}{l}\text { Unspeciated } \\
\text { acinetobacter }\end{array}$ & 5 & 1 & & 2 & & 2 \\
\hline A. berezinae & 4 & & & 3 & 1 & \\
\hline $\begin{array}{c}A . \\
\text { nosocomialis }\end{array}$ & 3 & 1 & 1 & & & 1 \\
\hline A. ursingii & 3 & & & & & 3 \\
\hline $\begin{array}{c}\text { Enterobacter } \\
\text { asburiae }\end{array}$ & 3 & 1 & & 1 & & 1 \\
\hline A. johnsonii & 2 & 1 & 1 & & & \\
\hline C. koseri & 2 & & 1 & & & 1 \\
\hline $\begin{array}{l}\text { P. vulgaris } \\
\text { group }\end{array}$ & 2 & & 2 & & & \\
\hline
\end{tabular}


Table 1. Cont.

\begin{tabular}{|c|c|c|c|c|c|c|}
\hline \multirow[t]{2}{*}{$\begin{array}{l}\text { Pathogens } \\
\text { Causing BSIs }\end{array}$} & \multicolumn{6}{|c|}{ Reported Cases of BSIs for Country ( $n=$ Number of Cases) } \\
\hline & $\begin{array}{c}\text { World } \\
\text { n. BSIs/n. Tot } \\
(66,729 / 319,581)\end{array}$ & $\begin{array}{c}\text { Asia } \\
\text { n. BSIs/n. Tot } \\
(6914 / 29,359)\end{array}$ & $\begin{array}{l}\text { West Europe } \\
\text { n. BSIs/n. Tot } \\
(20,897 / 77,554)\end{array}$ & $\begin{array}{c}\text { East Europe } \\
\text { n. BSIs/n. Tot } \\
(6689 / 29,313)\end{array}$ & $\begin{array}{c}\text { South America } \\
\text { n. BSIs/n. Tot } \\
(5188 / 19,462)\end{array}$ & $\begin{array}{c}\text { North America } \\
\text { n. BSIs/n. Tot } \\
(27,041 / 163,893)\end{array}$ \\
\hline $\begin{array}{c}\text { Acinetobacter } \\
\text { baumannii }\end{array}$ & 1 & & & & 1 & \\
\hline $\begin{array}{c}A . \\
\text { radioresistens }\end{array}$ & 1 & & & & & 1 \\
\hline E. hormaechei & 1 & & 1 & & & \\
\hline K. variicola & 1 & 1 & & & & \\
\hline $\begin{array}{l}\text { Pluralibacter } \\
\text { gergoviae }\end{array}$ & 1 & & 1 & & & \\
\hline P. vulgaris & 1 & & & & & 1 \\
\hline $\begin{array}{c}\text { Raoultella } \\
\text { ornithinolytica }\end{array}$ & 1 & & & & & 1 \\
\hline $\begin{array}{c}\text { Serratia } \\
\text { liquefaciens }\end{array}$ & 1 & & & & 1 & \\
\hline S. rubidaea & 1 & & & & & 1 \\
\hline $\begin{array}{l}\text { Providencia } \\
\text { (unspeciated) }\end{array}$ & 1 & & & & 1 & \\
\hline $\begin{array}{c}\text { Raoultella } \\
\text { (unspeciated) }\end{array}$ & 1 & & & & & 1 \\
\hline $\begin{array}{c}\text { Salmonella } \\
\text { (unspeciated) }\end{array}$ & 1 & 1 & & & & \\
\hline $\begin{array}{c}\text { Serratia } \\
\text { (unspeciated) }\end{array}$ & 1 & & & & 1 & \\
\hline
\end{tabular}

Meanwhile, BSIs caused by extended-spectrum beta-lactamase-producing Enterobacteriaceae (ESBL-PE) are spreading massively worldwide.

The epidemiology of BSIs changes even according to the setting of their development.

Escherichia coli, Staphylococcus aureus, Klebsiella pneumoniae, and Streptococcus pneumoniae are the pathogens causing the largest portions of community acquired BSIs, while Pseudomonas aeruginosae is the cause of only 5\% of community BSIs, especially in compromised patients. Patients who are immunosuppressed, who have had recent urinary tract infections, or recent pneumonia are most predisposed to P. aeruginosae BSIs. In this population, the prevalence of multidrug-resistant (MDR) isolates has been reported.

In the case of BSIs acquired in a hospital setting, according to the data collected from 1997 to 2016 (SENTRY network), 22\% were caused by S. aureus, 16\% by E. coli, 9\% by K. pneumoniae, and $8 \%$ by $P$. aeruginosae [12].

The SENTRY Antimicrobial Surveillance Program, established in 1997, is one of the longest running antimicrobial surveillance networks in the world. It monitors worldwide pathogens and the changes in resistance patterns over time. The network is composed of numerous medical centers and hospital sites that participate in the program and collect data on the prevalence of different types of infections and microorganisms in their daily clinical practice. All data collected from the network are then made available and organized in the free SENTRY database.

Among the pathogens causing BSIs, the MDR species are listed in Table 2. 
Table 2. MDR bacteria causing BSIs from SENTRY database.

\begin{tabular}{|c|c|c|c|c|c|c|}
\hline \multicolumn{7}{|c|}{ MDR Bacteria Causing BSIs Form SENTRY Database } \\
\hline Pathogen & World & Asia & West Europe & East Europe & North America & South America \\
\hline K. pneumoniae & 1882 & 150 & 551 & 561 & 285 & 335 \\
\hline Escherichia coli & 1747 & 266 & 612 & 285 & 420 & 164 \\
\hline $\begin{array}{c}\text { A. baumannii-calcoaceticus } \\
\text { species complex }\end{array}$ & 855 & 98 & 188 & 345 & 69 & 155 \\
\hline Pseudomonas aeruginosae & 612 & 41 & 172 & 175 & 149 & 75 \\
\hline Proteus mirabilis & 351 & 13 & 142 & 50 & 132 & 14 \\
\hline E. cloacae species complex & 180 & 22 & 22 & 18 & 70 & 48 \\
\hline Serratia marcescens & 124 & 2 & 33 & 34 & 23 & 32 \\
\hline E. cloacae & 114 & 12 & 44 & 23 & 21 & 14 \\
\hline Morganella morganii & 87 & 3 & 23 & 10 & 45 & 6 \\
\hline K. oxytoca & 59 & 1 & 21 & 8 & 21 & 8 \\
\hline Providencia stuartii & 54 & & 12 & 9 & 29 & 4 \\
\hline Klebsiella aerogenes & 41 & 5 & 15 & 5 & 13 & 3 \\
\hline C. freundii species complex & 25 & 3 & 8 & 1 & 12 & 1 \\
\hline Citrobacter freundii & 14 & & 7 & & 7 & \\
\hline Hafnia alvei & 14 & & 9 & 1 & 4 & \\
\hline A. lwoffii & 7 & & & 2 & 3 & 2 \\
\hline A. pittii & 7 & 1 & 2 & 2 & 2 & \\
\hline Providencia rettgeri & 5 & & & & 4 & 1 \\
\hline unspeciated Acinetobacter & 5 & 1 & & 2 & 2 & \\
\hline A. berezinae & 4 & & & 3 & & 1 \\
\hline A. nosocomialis & 3 & 1 & 1 & & 1 & \\
\hline A. ursingii & 3 & & & & 3 & \\
\hline Enterobacter asburiae & 3 & 1 & & 1 & 1 & \\
\hline A. johnsonii & 2 & 1 & 1 & & & \\
\hline C. koseri & 2 & & 1 & & 1 & \\
\hline P. vulgaris group & 2 & & 2 & & & \\
\hline Acinetobacter baumannii & 1 & & & & & 1 \\
\hline A. radioresistens & 1 & & & & 1 & \\
\hline E. hormaechei & 1 & & 1 & & & \\
\hline K. variicola & 1 & 1 & & & & \\
\hline Pluralibacter gergoviae & 1 & & 1 & & & \\
\hline P. vulgaris & 1 & & & & 1 & \\
\hline Raoultella ornithinolytica & 1 & & & & 1 & \\
\hline Serratia liquefaciens & 1 & & & & & 1 \\
\hline S. rubidaea & 1 & & & & 1 & \\
\hline Providencia (unspeciated) & 1 & & & & & 1 \\
\hline Raoultella (unspeciated) & 1 & & & & 1 & \\
\hline Salmonella (unspeciated) & 1 & 1 & & & & \\
\hline Serratia (unspeciated) & 1 & & & & & 1 \\
\hline
\end{tabular}


Between 1997 and 2016, the prevalence of MDR Enterobacteriaceae has increased from $6.2 \%$ to $15.8 \%$, with a high rate of non-fermentative Gram-negative bacilli (GNB). Colistin was the only antimicrobial with a predictable $97 \%$ efficacy against Acinetobacter BaumanniiAcinetobacter calcoaceticus complex.

Data collected from 2013 until 2019 and available on the SENTRY database report that the most frequent MDR pathogen causing BSIs is K. pneumoniae with 1882 global cases (high prevalence in West Europe, East Europe and South America), followed by Escherichia coli with 1747 global cases (high prevalence in West Europe and North America). A. baumannii-calcoaceticus species complex is reported to be responsible for 855 global cases, the majority of which were in East Europe. The MDR P. aeruginosae caused 612 cases of BSIs, predominantly in West Europe, East Europe, and North America.

The paragraph beneath describes the MDR mechanisms and MDR species related to BSIs with a special focus on ICU acquired BSIs.

\section{Microbiology}

In healthcare settings, the emergence of MDR organisms is a major concern. The global spread and diffusion of MDR pathogens such as oxacillin-resistant Staphylococcus aureus (ORSA), vancomycin-resistant Enterococcus spp. (VRE), and MDR Gram-negative bacilli (GNB) (including extended-spectrum- $\beta$-lactamase [ESBL] producers), carbapenemresistant Enterobacteriaceae (CRE), and MDR nonfermenters such as Pseudomonas aeruginosae and Acinetobacter spp. have evidenced the capability of surviving treatment with many antimicrobial agents, even the most recent ones.

This capability is due to numerous mechanisms, including alterations of cell permeability that can reduce intracellular antibiotic concentration, [13] antibiotic alteration, antimicrobial inactivation, [14] modifications to antibiotic target sites [15], and biofilm formation. We provide a quick summary of the main mechanisms of resistance in the pathogens most frequently responsible of BSIs. In Table 3, we summarize the total number of isolates by ESKAPE pathogens and the total number of BSI cases caused by these pathogens with related resistance profiles (data available on SENTRY dataset).

Table 3. Summary of the number of isolates by ESKAPE pathogens and the total number of BSI cases due to these pathogens with related resistance profiles (data available on SENTRY dataset).

\begin{tabular}{|c|c|c|c|}
\hline Pathogen & $\begin{array}{l}\text { n. Cases of Infections } \\
(\mathbf{n}=\text { Number })\end{array}$ & $\begin{array}{l}\text { n. BSIs Reported } \\
\text { (n = Number) }\end{array}$ & $\begin{array}{c}\text { Frequent Resistance Profiles } \\
\text { in BSIs }\end{array}$ \\
\hline Enterococcus spp. & 15,022 & 5154 & Van-A \\
\hline S. aureus & 69,918 & 13,608 & MRSA (less frequent VRSA) \\
\hline K. pneumoniae & 26,701 & 6901 & NMD-1 \\
\hline Acinetobacter spp. & 7151 & 1372 & IMP and OXA \\
\hline P. aeruginosae & 28,096 & 3264 & ESBLs, KPC, VIM and IMP \\
\hline Enterobacter spp. & 11,597 & 2241 & ESBLs \\
\hline
\end{tabular}

Abbreviations-Van-A: vancomycin and teicoplanin resistance pattern; MRSA: methicillin-resistant S. aureus; VRSA: vancomycin resistant S. aureus; NMD-1: New Delhi metallo-beta-lactamase; IMP: imipenem metallo-beta-lactamases; OXA: oxacillinase serine beta-lactamases; ESBLs: extended spectrum beta-lactamases; KPC: K. pneumoniae carbapenemase; VIM: Verona integron-encoded metallo $\beta$-lactamases.

\subsection{Enterococcus spp.}

Enterococci are a family of Gram-negative bacteria that inhabit the intestines of humans and other animals. They are opportunistic pathogens capable of developing severe infections, especially E. faecium and E. faecalis species [16]. In recent years, several vancomycinresistant strains have been identified in this family, represented mainly by E. faecium. Six types of vancomycin-resistant Enterococcus have been identified: Van-A, Van-B, Van-C, Van-D, Van-E, and Van-G. Van-A is the most common, showcasing the highest levels of resistance to glycopeptides [17]. The presence of these strains is usually endogenous and is 
easily transmitted in healthcare settings. Vancomycin-resistant enterococci had recorded an increasing incidence in North America. Data from 2002 show that more than half of the isolated enterococci strains show resistance to this. In Europe and the United Kingdom, the presence of strains resistant to vancomycin is less frequent, but in recent years the incidence of these strains has been increasing [18]. Resistance profiles of strains of Enterococcus spp. isolated in BSIs are shown in Table 4.

Table 4. Enterococcus spp. isolates from bloodstream infections' resistance profiles.

\begin{tabular}{|c|c|c|c|c|c|c|c|c|c|c|c|c|}
\hline \multirow{2}{*}{ Agent } & \multirow{2}{*}{ MIC50 } & \multirow{2}{*}{ MIC90 } & \multirow{2}{*}{ Range } & \multirow{2}{*}{ Count } & \multicolumn{4}{|c|}{ CLSI $^{a}$} & \multicolumn{4}{|c|}{ EUCAST $^{a}$} \\
\hline & & & & & $\% S$ & $\% I$ & $\% R$ & Count & $\% S$ & $\% I$ & $\% R$ & Count \\
\hline $\begin{array}{l}\text { Amoxicillin- } \\
\text { clavulanic } \\
\text { acid }\end{array}$ & $\leq 1$ & $>8$ & $\leq 1$ to $>8$ & 1451 & & & & & & & & \\
\hline $\begin{array}{l}\text { Piperacillin- } \\
\text { tazobactam }\end{array}$ & 8 & $>16$ & $\leq 2$ to $>16$ & 3042 & & & & & 64.9 & 0.3 & 34.8 & 3040 \\
\hline Imipenem & 1 & $>8$ & $\leq 0.12$ to $>8$ & 1458 & & & & & & & & \\
\hline Meropenem & 8 & $>8$ & 0.25 to $>8$ & 1458 & & & & & & & & \\
\hline Cefepime & $>16$ & $>16$ & $\leq 0.5$ to $>16$ & 1458 & & & & & & & & \\
\hline Ceftaroline & 4 & $>8$ & $\leq 0.25$ to $>8$ & 5045 & & & & & & & & \\
\hline Ceftriaxone & $>8$ & $>8$ & $\leq 0.06$ to $>8$ & 1458 & & & & & & & & \\
\hline $\begin{array}{l}\text { Trimethoprim- } \\
\text { sulfamethoxazole }\end{array}$ & $\leq 0.5$ & $>4$ & $\leq 0.5$ to $>4$ & 1458 & & & & & & & & \\
\hline Teicoplanin & $\leq 2$ & $>16$ & $\leq 2$ to $>16$ & 5145 & 85.3 & 2.1 & 12.7 & 5145 & 84.7 & & 15.3 & 5145 \\
\hline Vancomycin & $\overline{1}$ & $>16$ & $\leq 0.5$ to $>16$ & 5145 & 83.1 & 0.6 & 16.3 & 5145 & 83.1 & & 16.9 & 5145 \\
\hline Tigecycline & $\leq 0.06$ & 0.12 & $\leq 0.06$ to $>0.5$ & 5142 & & & & & 99.6 & & 0.4 & 4971 \\
\hline Clindamycin & $>2$ & $>2$ & $\leq 0.25$ to $>2$ & 2246 & & & & & & & & \\
\hline Daptomycin & 1 & 2 & $\leq 0.25$ to $>8$ & 5144 & & & & & & & & \\
\hline Erythromycin & $>16$ & $>16$ & $\leq 0.12$ to $>16$ & 2245 & 8.2 & 27.5 & 64.2 & 2245 & & & & \\
\hline Linezolid & 1 & 2 & $\leq 0.25$ to $>8$ & 5145 & 99.6 & 0.2 & 0.2 & 5145 & 99.8 & & 0.2 & 5145 \\
\hline Ampicillin & 1 & $>8$ & $\leq 0.5$ to $>8$ & 5150 & 66.0 & & 34.0 & 5150 & 65.7 & 0.4 & 34.0 & 5150 \\
\hline Penicillin & 4 & $>8$ & $\leq 0.06$ to $>8$ & 1448 & 61.8 & & 38.2 & 1448 & & & & \\
\hline Ciprofloxacin & $>4$ & $>4$ & $\leq 0.03$ to $>4$ & 1457 & 36.8 & 8.6 & 54.6 & 1457 & 47.4 & & $52.6^{b}$ & 1457 \\
\hline Levofloxacin & 4 & $>4$ & $\leq 0.5$ to $>4$ & 5151 & 48.4 & 2.0 & 49.6 & 5151 & 50.4 & & $49.6^{b}$ & 5151 \\
\hline Moxifloxacin & 2 & $>4$ & $\leq 0.25$ to $>4$ & 4262 & & & & & & & & \\
\hline Doxycycline & 8 & $>8$ & $\leq 0.06$ to $>8$ & 1353 & 46.0 & 34.5 & 19.5 & 1353 & & & & \\
\hline Minocycline & 8 & $>8$ & $\leq 1$ to $>8$ & 3691 & 48.1 & 19.9 & 32.1 & 3691 & & & & \\
\hline Tetracycline & $>8$ & $>8$ & $\leq 1$ to $>8$ & 5141 & 32.9 & 1.0 & 66.1 & 5141 & & & & \\
\hline
\end{tabular}

${ }^{a}$ Criteria as published by CLSI (2021) and EUCAST (2021), ${ }^{\mathrm{b}}$ Uncomplicated UTI only. Organisms included: Enterococcus avium (20), E. casseliflavus (44), E. cecorum (1), E. durans (11), E. faecalis (3002), E. faecium (1980), E. gallinarum (68), E. hirae (13), E. mundtii (2), and E. raffinosus (13). Report generated from MVP (https:/ / sentry-mvp.jmilabs.com, assessed on 4 June 2021), a product of JMI Laboratories, on 5 June 2021 11:06:30 GMT/UTC. The data and information are available in the SENTRY Antimicrobial Surveillance Program dataset.

\subsection{Staphylococcus aureus}

S. aureus is a Gram-positive non-motile bacterium without a notable capsule. It is normally present in the majority of adults in the skin and the mucosa of the anterior portion of the nose and pharynx. To date, the majority of isolates of this family show resistance to beta-lactam antibiotics and about $25 \%$ are methicillin-resistant [19]. However, the prevalence of methicillin-resistant Staphylococcus aureus (MRSA) infection may grow up to $50 \%$ in some geographical locations. In most cases, as the first-line antimicrobial, glycopeptide antibiotics (i.e., vancomycin and teicoplanin), are chosen even if the inappropriate use of these antibiotics has led some strains to become vancomycin-intermediate and vancomycin-resistant [20]. Often the vancomycin-intermediate S. aureus is less susceptible to teicoplanin too. VRSA, even if is less frequently encountered, is worthy of attention because of the interspecies exchange of genetic resistance genes from VRE, which results in resistances to multiple drugs [21]. Resistance profiles of strains of S.aureus isolated in BSIs are shown in Table 5. 
Table 5. Staphylococcus aureus isolates from bloodstream infections' resistance profiles.

\begin{tabular}{|c|c|c|c|c|c|c|c|c|c|c|c|c|}
\hline \multirow{2}{*}{ Agent } & \multirow{2}{*}{ MIC50 } & \multirow{2}{*}{ MIC90 } & \multirow{2}{*}{ Range } & \multirow{2}{*}{ Count } & \multicolumn{4}{|c|}{ CLSI $^{a}$} & \multicolumn{4}{|c|}{ EUCAST $^{a}$} \\
\hline & & & & & $\% \mathrm{~S}$ & $\% \mathrm{I}$ & $\% R$ & Count & $\% \mathrm{~S}$ & $\%$ I & $\% R$ & Count \\
\hline $\begin{array}{l}\text { Amoxicillin- } \\
\text { clavulanic } \\
\text { acid }\end{array}$ & $\leq 1$ & $>8$ & $\leq 1$ to $>8$ & 4055 & 65.7 & & 34.3 & 4055 & & & & \\
\hline $\begin{array}{l}\text { Piperacillin- } \\
\text { tazobactam }\end{array}$ & 1 & $>16$ & $\leq 0.5$ to $>16$ & 8387 & 66.0 & & 34.0 & 8387 & 66.0 & & 34.0 & 8387 \\
\hline Imipenem & $\leq 0.12$ & $>8$ & $\leq 0.12$ to $>8$ & 4021 & 65.8 & & 34.2 & 4021 & & & & \\
\hline Meropenem & 0.12 & $>8$ & $\leq 0.06$ to $>8$ & 4023 & 65.8 & & 34.2 & 4023 & & & & \\
\hline Cefepime & 4 & $>16$ & $\leq 0.5$ to $>16$ & 4026 & 65.8 & & 34.2 & 4026 & & & & \\
\hline Ceftaroline & 0.25 & 1 & $\leq 0.06$ to 8 & 13,099 & 95.8 & 4.2 & $0.1^{\mathrm{b}}$ & 13,099 & $\begin{array}{l}95.8 \\
95.8\end{array}$ & 4.1 & $\begin{array}{l}0.1^{\mathrm{c}} \\
4.2^{\mathrm{d}}\end{array}$ & $\begin{array}{l}13,099 \\
13,099\end{array}$ \\
\hline Ceftriaxone & 4 & $>8$ & $\leq 0.25$ to $>8$ & 13,608 & 66.3 & & 33.7 & 13,608 & & & & \\
\hline $\begin{array}{l}\text { Trimethoprim- } \\
\text { sulfamethoxazole }\end{array}$ & $\leq 0.5$ & $\leq 0.5$ & $\leq 0.5$ to $>4$ & 13,608 & 98.3 & & 1.7 & 13,608 & 98.3 & 0.2 & 1.4 & 13,608 \\
\hline Teicoplanin & $\leq 2$ & $\leq 2$ & $\leq 2$ to 16 & 13,606 & $>99.9$ & $<0.1$ & 0.0 & 13,606 & 99.6 & & 0.4 & 13,606 \\
\hline Vancomycin & $\overline{1}$ & $\overline{1}$ & $\leq 0.12$ to 2 & 13,607 & 100.0 & 0.0 & 0.0 & 13,607 & 100.0 & & 0.0 & 13,607 \\
\hline Tigecycline & 0.06 & 0.12 & $\leq 0.015$ to 1 & 13,602 & $>99.9$ & & & 13,602 & $>99.9$ & & $<0.1$ & 13,602 \\
\hline Clindamycin & $\leq 0.25$ & $>2$ & $\leq 0.25$ to $>2$ & 13,608 & 87.6 & 0.1 & 12.3 & 13,608 & 87.4 & 0.2 & 12.4 & 13,608 \\
\hline Daptomycin & 0.25 & 0.5 & $\leq 0.12$ to 4 & 13,607 & 99.9 & & & 13,607 & 99.9 & & 0.1 & 13,607 \\
\hline Azithromycin & 0.5 & $>4$ & $\leq 0.03$ to $>4$ & 5034 & 59.2 & 1.2 & 39.6 & 5034 & 58.4 & 0.8 & 40.8 & 5034 \\
\hline Erythromycin & 0.25 & $>8$ & $\leq 0.12$ to $>8$ & 13,603 & 59.1 & 4.4 & 36.5 & 13,603 & 59.5 & 1.6 & 38.9 & 13,603 \\
\hline Linezolid & 1 & 2 & $\leq 0.12$ to 4 & 13,607 & 100.0 & & 0.0 & 13,607 & 100.0 & & 0.0 & 13,607 \\
\hline Oxacillin & 0.5 & $>2$ & $\leq 0.25$ to $>2$ & 13,608 & 66.3 & & 33.7 & 13,608 & 66.3 & & 33.7 & 13,608 \\
\hline Penicillin & $>2$ & $>2$ & $\leq 0.06$ to $>2$ & 8377 & 17.5 & & $82.5^{\mathrm{e}}$ & 8377 & 17.5 & & 82.5 & 8377 \\
\hline Ciprofloxacin & 0.5 & $>4$ & 0.06 to $>4$ & 4021 & 68.4 & 1.8 & 29.7 & 4021 & & & & \\
\hline Levofloxacin & 0.25 & $>4$ & $\leq 0.12$ to $>4$ & 13,604 & 71.4 & 0.5 & 28.1 & 13,604 & & & & \\
\hline Moxifloxacin & $\leq 0.12$ & 4 & $\leq 0.12$ to $>4$ & 11,069 & 72.0 & 5.6 & 22.4 & 11,069 & 71.6 & & 28.4 & 11,069 \\
\hline Doxycycline & $\leq 0.06$ & 0.25 & $\leq 0.06$ to $>8$ & 13,102 & 98.1 & 1.6 & 0.3 & 13,102 & 95.2 & 1.8 & 3.1 & 13,102 \\
\hline Minocycline & $\leq 0.06$ & 0.12 & $\leq 0.06$ to $>8$ & 9581 & 98.9 & 0.6 & 0.5 & 9581 & 97.7 & & 2.3 & 9581 \\
\hline Tetracycline & $\leq 0.5$ & 1 & $\leq 0.5$ to $>8$ & 13,602 & 92.6 & 0.8 & 6.6 & 13,602 & 91.3 & 0.6 & 8.1 & 13,602 \\
\hline
\end{tabular}

${ }^{a}$ Criteria as published by CLSI (2021) and EUCAST (2021). ${ }^{b}$ Intermediate is interpreted as susceptible-dose dependent. ${ }^{c}$ Using other than pneumonia breakpoints. ${ }^{\mathrm{d}}$ Using pneumonia breakpoints. ${ }^{\mathrm{e}}$ Oxacillin non-susceptible is reported as resistant. Organisms included: Staphylococcus aureus $(13,608)$. The data and information are available in the SENTRY Antimicrobial Surveillance Program dataset.

\subsection{Klebsiella pneumoniae}

K. pneumoniae is a Gram-negative, opportunistic pathogen. Among the members of the family Enterobacteriaceae, it is the most often found in healthcare-related infections. They are implicated in a wide range of diseases and are practically ubiquitous in nature. Infections can spread rapidly among patients hospitalized for other conditions, but the most problematic aspect is the emergence of several beta-lactamase enzymes, able to give these strains resistance to beta-lactam antimicrobials (i.e., penicillins, cephalosporins, and carbapenems). The conventional use of carbapenems to manage resolute Gram-negative infections is growing the prevalence of carbapenem-resistant K. pneumoniae [22]. The spread of the K. pneumoniae super enzyme NDM-1 (New Delhi metallo-beta-lactamase-1) has boosted the incidence of carbapenem-resistant $K$. pneumoniae isolates so that other antibiotics are rarely used [23]. The resistance profiles of strains of K.pneumoniae isolated in BSIs are shown in Table 6. 
Table 6. Klebsiella pneumoniae isolates from bloodstream infections' resistance profiles.

\begin{tabular}{|c|c|c|c|c|c|c|c|c|c|c|c|c|}
\hline \multirow{2}{*}{ Agent } & \multirow{2}{*}{ MIC50 } & \multirow{2}{*}{ MIC90 } & \multirow{2}{*}{ Range } & \multirow{2}{*}{ Count } & \multicolumn{4}{|c|}{ CLSI $^{a}$} & \multicolumn{4}{|c|}{ EUCAST $^{a}$} \\
\hline & & & & & $\% \mathrm{~S}$ & $\% \mathbf{I}$ & $\% R$ & Count & $\% S$ & $\% \mathbf{I}$ & $\% R$ & Count \\
\hline Amikacin & 1 & 8 & $\leq 0.25$ to $>32$ & 6897 & 93.5 & 3.0 & 3.5 & 6897 & 91.3 & & $8.7^{\mathrm{b}}$ & 6897 \\
\hline Gentamicin & $\leq 1$ & $>8$ & $\leq 1$ to $>8$ & 6899 & 81.6 & 0.9 & 17.5 & 6899 & 81.0 & & $19.0^{\mathrm{b}}$ & 6899 \\
\hline Tobramycin & 0.5 & $>8$ & $\leq 0.12$ to $>8$ & 6897 & 74.1 & 4.8 & 21.1 & 6897 & 72.5 & & $27.5^{b}$ & 6897 \\
\hline $\begin{array}{l}\text { Amoxicillin- } \\
\text { clavulanic } \\
\text { acid }\end{array}$ & 4 & $>8$ & $\leq 1$ to $>8$ & 4662 & 67.6 & 8.6 & 12.1 & 4662 & & & & \\
\hline $\begin{array}{l}\text { Ampicillin- } \\
\text { sulbactam }\end{array}$ & 8 & $>32$ & $\leq 0.5$ to $>32$ & 6901 & 56.4 & 7.0 & 36.7 & 6901 & 56.4 & & $43.6^{c}$ & 6901 \\
\hline $\begin{array}{l}\text { Cefoperazone- } \\
\text { sulbactam }\end{array}$ & $\leq 0.25$ & $>32$ & $\leq 0.25$ to $>32$ & 5723 & 78.1 & & $21.9^{\mathrm{d}}$ & 5723 & & & & \\
\hline $\begin{array}{l}\text { Ceftazidime- } \\
\text { avibactam }\end{array}$ & 0.12 & 1 & $\leq 0.015$ to $>32$ & 1074 & 98.5 & & 1.5 & 1074 & 98.5 & & 1.5 & 1074 \\
\hline $\begin{array}{l}\text { Ceftolozane- } \\
\text { tazobactam }\end{array}$ & 0.25 & $>16$ & $\leq 0.12$ to $>16$ & 1073 & 84.5 & 1.4 & 14.1 & 1073 & 84.5 & & 15.5 & 1073 \\
\hline $\begin{array}{l}\text { Piperacillin- } \\
\text { tazobactam }\end{array}$ & 4 & $>64$ & $\leq 0.5$ to $>64$ & 6891 & 78.1 & 5.1 & 16.8 & 6891 & 71.9 & & 28.1 & 6891 \\
\hline Doripenem & $\leq 0.12$ & 2 & $\leq 0.12$ to $>4$ & 5827 & 89.5 & 0.8 & 9.7 & 5827 & 89.5 & 0.8 & 9.7 & 5827 \\
\hline Ertapenem & $\overline{0} .015$ & $>2$ & $\leq 0.008$ to $>2$ & 2888 & 85.2 & 1.0 & 13.8 & 2888 & 85.2 & & 14.8 & 2888 \\
\hline Imipenem & $\leq 0.12$ & 2 & $\leq 0.12$ to $>8$ & 6899 & 89.4 & 1.0 & 9.6 & 6899 & 90.4 & 1.2 & 8.4 & 6899 \\
\hline Meropenem & $\leq 0.06$ & 2 & $\leq 0.06$ to $>8$ & 6899 & 89.4 & 0.8 & 9.8 & 6899 & $\begin{array}{l}90.2 \\
90.2\end{array}$ & 1.7 & $\begin{array}{l}9.8^{e} \\
8.0^{f}\end{array}$ & $\begin{array}{l}6899 \\
6899\end{array}$ \\
\hline Cefepime & $\leq 0.5$ & $>16$ & $\leq 0.5$ to $>16$ & 6899 & 70.9 & 2.5 & $26.6^{\mathrm{g}}$ & 6899 & 69.9 & 2.0 & 28.1 & 6899 \\
\hline Cefoperazone & 0.5 & $>32$ & $\leq 0.25$ to $>32$ & 1450 & 68.1 & 0.9 & $31.0^{\mathrm{d}}$ & 1450 & & & & \\
\hline Cefoxitin & 4 & $>16$ & 1 to $>16$ & 883 & 77.5 & 4.6 & 17.9 & 883 & & & & \\
\hline Ceftaroline & 0.12 & $>16$ & $\leq 0.03$ to $>16$ & 6738 & 65.0 & 2.0 & 33.0 & 6738 & 65.0 & & 35.0 & 6738 \\
\hline Ceftazidime & 0.25 & $>16$ & $\leq 0.12$ to $>16$ & 6901 & 70.3 & 2.3 & 27.4 & 6901 & 68.4 & 1.9 & 29.7 & 6901 \\
\hline Ceftriaxone & $\leq 0.06$ & $>8$ & $\leq 0.06$ to $>8$ & 6899 & 68.8 & 0.6 & 30.6 & 6899 & $\begin{array}{l}68.8 \\
68.8\end{array}$ & 0.6 & $\begin{array}{l}31.2^{\mathrm{e}} \\
30.6^{\mathrm{f}}\end{array}$ & $\begin{array}{l}6899 \\
6899\end{array}$ \\
\hline Cefuroxime & 4 & $>64$ & $\leq 0.5$ to $>64$ & 2458 & $\begin{array}{l}53.5 \\
58.8\end{array}$ & $\begin{array}{l}8.5 \\
3.3\end{array}$ & $\begin{array}{l}37.9^{h} \\
37.9^{i}\end{array}$ & $\begin{array}{l}2458 \\
2458\end{array}$ & 58.8 & & $41.2^{j}$ & 2458 \\
\hline $\begin{array}{l}\text { Trimethoprim- } \\
\text { sulfamethoxazole }\end{array}$ & $\leq 0.5$ & $>4$ & $\leq 0.5$ to $>4$ & 6893 & 67.0 & & 33.0 & 6893 & 67.0 & 1.1 & 31.9 & 6893 \\
\hline Tigecycline & 0.5 & 1 & $\leq 0.06$ to 8 & 6893 & 98.0 & 1.7 & $0.2^{\mathrm{k}}$ & 6893 & & & & \\
\hline Colistin & $\leq 0.5$ & $\leq 0.5$ & $\leq 0.5$ to $>8$ & 6848 & & & & & 95.8 & & 4.2 & 6848 \\
\hline Polymyxin B & 1 & 1 & $\leq 0.25$ to $>8$ & 1757 & & & & & & & & \\
\hline Aztreonam & $\leq 0.12$ & $>16$ & $\leq 0.12$ to $>16$ & 6899 & 70.5 & 0.8 & 28.7 & 6899 & 69.2 & 1.3 & 29.5 & 6899 \\
\hline Ciprofloxacin & $\leq 0.03$ & $>4$ & $\leq 0.03$ to $>4$ & 6884 & 65.2 & 4.1 & 30.7 & 6884 & 65.2 & 4.1 & 30.7 & 6884 \\
\hline Levofloxacin & $\leq 0.12$ & $>4$ & $\leq 0.12$ to $>4$ & 6884 & 70.9 & 5.0 & 24.1 & 6884 & 70.9 & 5.0 & 24.1 & 6884 \\
\hline Moxifloxacin & $\leq 0.25$ & $>4$ & $\leq 0.25$ to $>4$ & 5465 & & & & & 60.3 & & 39.7 & 5465 \\
\hline Doxycycline & 2 & $>8$ & 0.12 to $>8$ & 6372 & 69.5 & 6.6 & 23.9 & 6372 & & & & \\
\hline Minocycline & 2 & $>8$ & $\leq 0.06$ to $>8$ & 6521 & 78.8 & 7.7 & 13.4 & 6521 & & & & \\
\hline Tetracycline & 2 & $>8$ & $\leq 0.5$ to $>8$ & 6526 & 68.6 & 3.8 & 27.6 & 6526 & & & & \\
\hline
\end{tabular}

${ }^{a}$ Criteria as published by CLSI (2021) and EUCAST (2021). ${ }^{b}$ For infections originating from the urinary tract. For systemic infections, aminoglycosides must be used in combination with other active therapy. ${ }^{\mathrm{c}}$ These breakpoints for oral administration are relevant for uncomplicated urinary tract infections only. ${ }^{\mathrm{d}}$ The cefoperazone breakpoints were applied following US FDA criteria. ${ }^{\mathrm{e}}$ Using meningitis breakpoints. ${ }^{\mathrm{f}}$ Using non-meningitis breakpoints. ${ }^{\mathrm{g}}$ Intermediate is interpreted as susceptible-dose dependent. ${ }^{\mathrm{h}}$ Using oral breakpoints. ${ }^{\mathrm{i}}$ Using parenteral breakpoints. ${ }^{j}$ Using oral, uncomplicated urinary tract infection only breakpoints. ${ }^{k}$ US FDA breakpoints were applied. Organisms included: Klebsiella pneumoniae (6901). Report generated using MVP (https:/ / sentry-mvp.jmilabs.com, assessed on 4 June 2021), a product of JMI Laboratories, on 5 June 2021 11:09:47 GMT/UTC. The data and information are available in the SENTRY Antimicrobial Surveillance Program dataset.

\subsection{Acinetobacter baumannii}

Acinetobacter are Gram-negative, obligate, aerobic bacteria. They are ubiquitous and can survive up to a month on dry surfaces and are commonly found on the skin of healthcare workers, meaning that they are widely distributed in the environment and readily contaminate the hospital environment. [24] Occasionally, they can be the cause of urinary or respiratory infections in immunocompromised patients. There are many Acinetobacter species; all of them can cause human disease, but Acinetobacter baumannii is responsible for almost all infections [25].

They are resistant to numerous antibiotics because they produce beta-lactamases such as imipenem metallo-beta-lactamases and oxacillinase serine beta-lactamases which 
give the bacteria resistance to imipenem and colistin and, if associated, to almost all antibiotics [26]. Resistance profiles of strains of Acinetobacter baumanii isolated in BSIs are shown in Table 7.

Table 7. Acinetobacter isolates from bloodstream infections' resistance profiles.

\begin{tabular}{|c|c|c|c|c|c|c|c|c|c|c|c|c|}
\hline \multirow{2}{*}{ Agent } & \multirow{2}{*}{ MIC50 } & \multirow{2}{*}{ MIC90 } & \multirow{2}{*}{ Range } & \multirow{2}{*}{ Count } & \multicolumn{4}{|c|}{ CLSI $^{a}$} & \multicolumn{4}{|c|}{ EUCAST $^{a}$} \\
\hline & & & & & $\% S$ & $\% \mathbf{I}$ & $\% \mathbf{R}$ & Count & $\% S$ & $\%$ I & $\% R$ & Count \\
\hline Amikacin & $>32$ & $>32$ & $\leq 0.25$ to $>32$ & 1370 & 46.4 & 2.6 & 50.9 & 1370 & 44.7 & & $55.3^{b}$ & 1370 \\
\hline Gentamicin & $>8$ & $>8$ & $\leq 1$ to $>8$ & 1370 & 44.7 & 3.9 & 51.4 & 1370 & 44.7 & & $55.3^{b}$ & 1370 \\
\hline Tobramycin & 2 & $>8$ & $\leq 0.12$ to $>8$ & 1370 & 56.2 & 1.2 & 42.6 & 1370 & 56.2 & & $43.8^{b}$ & 1370 \\
\hline $\begin{array}{l}\text { Amoxicillin- } \\
\text { clavulanic } \\
\text { acid }\end{array}$ & $>8$ & $>8$ & $\leq 1$ to $>8$ & 666 & & & & & & & & \\
\hline $\begin{array}{l}\text { Ampicillin- } \\
\text { sulbactam }\end{array}$ & 32 & $>32$ & $\leq 0.5$ to $>32$ & 1372 & 39.2 & 8.1 & 52.7 & 1372 & & & & \\
\hline $\begin{array}{l}\text { Cefoperazone- } \\
\text { sulbactam }\end{array}$ & 16 & $>32$ & $\leq 1$ to $>32$ & 1184 & & & & & & & & \\
\hline $\begin{array}{l}\text { Piperacillin- } \\
\text { tazobactam }\end{array}$ & $>64$ & $>64$ & $\leq 0.5$ to $>64$ & 1359 & 33.3 & 3.4 & 63.3 & 1359 & & & & \\
\hline Doripenem & $>4$ & $>4$ & $\leq 0.12$ to $>4$ & 1201 & 39.6 & 0.6 & 59.8 & 1201 & & & & \\
\hline Imipenem & $>8$ & $>8$ & $\leq 0.12$ to $>8$ & 1370 & 41.9 & 0.6 & 57.5 & 1370 & 41.9 & 0.6 & 57.5 & 1370 \\
\hline Meropenem & $>8$ & $>8$ & $\leq 0.06$ to $>8$ & 1370 & 40.4 & 1.1 & 58.5 & 1370 & $\begin{array}{l}40.4 \\
40.4\end{array}$ & 2.0 & $\begin{array}{l}59.6^{c} \\
57.6^{d}\end{array}$ & $\begin{array}{l}1370 \\
1370\end{array}$ \\
\hline Cefepime & $>16$ & $>16$ & $\leq 0.5$ to $>16$ & 1370 & 35.5 & 4.4 & 60.1 & 1370 & & & & \\
\hline Cefoperazone & $>32$ & $>32$ & 8 to $>32$ & 378 & & & & & & & & \\
\hline Ceftazidime & $>16$ & $>16$ & $\leq 0.25$ to $>16$ & 1372 & 34.4 & 3.9 & 61.7 & 1372 & & & & \\
\hline Ceftriaxone & $>8$ & $>8$ & 0.25 to $>8$ & 1026 & 17.1 & 0.0 & 0.0 & 1026 & & & & \\
\hline $\begin{array}{l}\text { Trimethoprim- } \\
\text { sulfamethoxazole }\end{array}$ & 4 & $>4$ & $\leq 0.5$ to $>4$ & 1371 & 48.1 & & 51.9 & 1371 & 48.1 & 2.5 & 49.5 & 1371 \\
\hline Tigecycline & 1 & 4 & $\leq 0.12$ to $>8$ & 1370 & & & & & & & & \\
\hline Colistin & $\leq 0.5$ & 2 & $\leq 0.5$ to $>8$ & 1368 & & & & & 92.1 & & 7.9 & 1368 \\
\hline Polymyxin B & 1 & 2 & $\leq 0.25$ to $>8$ & 443 & & & & & & & & \\
\hline Aztreonam & $>16$ & $>16$ & 0.25 to $>16$ & 1372 & & & & & & & & \\
\hline Ciprofloxacin & $>4$ & $>4$ & $\leq 0.03$ to $>4$ & 1370 & 37.3 & 0.4 & 62.3 & 1370 & & & & \\
\hline Levofloxacin & $>4$ & $>4$ & $\leq 0.12$ to $>4$ & 1372 & 38.6 & 3.7 & 57.7 & 1372 & 37.6 & 0.4 & 62.0 & 1372 \\
\hline Moxifloxacin & $>4$ & $>4$ & $\leq 0.25$ to $>4$ & 1122 & & & & & & & & \\
\hline Doxycycline & 1 & $>8$ & $\leq 0.06$ to $>8$ & 1124 & 65.4 & 1.3 & 33.3 & 1124 & & & & \\
\hline Minocycline & 0.5 & $>8$ & $\leq 0.06$ to $>8$ & 1348 & 75.8 & 6.7 & 17.5 & 1348 & & & & \\
\hline Tetracycline & $>8$ & $>8$ & $\leq 0.5$ to $>8$ & 1165 & 39.5 & 9.8 & 50.7 & 1165 & & & & \\
\hline
\end{tabular}

${ }^{a}$ Criteria as published by CLSI (2021) and EUCAST (2021). ${ }^{b}$ For infections originating from the urinary tract. For systemic infections, aminoglycosides must be used in combination with other active therapy. ${ }^{c}$ Using meningitis breakpoints. $\mathrm{d}$ Using non-meningitis breakpoints. Organisms included: Acinetobacter baumannii (1), A. baumannii-calcoaceticus species complex (1134), A. beijerinckii (1), A. berezinae (12), A. courvalinii (2), A. guillouiae (5), A. haemolyticus (2), A. johnsonii (12), A. junii (16), A. lwoffii (44), A. nosocomialis (6), A. pittii (18), A. radioresistens (24), A. schindleri (4), A. soli (3), A. towneri (1), A. ursingii (60), A. variabilis (6), and unspeciated Acinetobacter (21). The data and information are available in the SENTRY Antimicrobial Surveillance Program dataset.

\subsection{Pseudomonas aeruginosae}

P. aeruginosae, as much as Enterococci spp., is a Gram-negative facultative anaerobe. This pathogen is usually found in the normal gut flora. If compared to others MDR pathogens it is frequently isolated in immunocompromised hospitalized patients. P. aeruginosae usually shows a propensity to develop resistance during therapy, but the isolates from ICUs show an intrinsic reduced susceptibility to several antibacterial agents above all the carbapenems. P. aeruginosae mostly develop a resistance against imipenem by the over-production of AmpC $\beta$-lactamases, the over expression of efflux pumps, the reduction of porin permeability [16], and finally the production of ESBLs (extended spectrum beta-lactamases), KPC (K. pneumoniae carbapenemase), VIM (Verona integron-encoded metallo $\beta$-lactamases), and imipenem metallo- $\beta$-lactamases. Furthermore, a combination of all the different lactamases described above can be carried by the same plasmid, leading to high rates of both carbapenem and fluoroquinolone resistance [27]. However, colistin is still effective in a high percentage of cases [26]. Resistance profiles of strains of P.aeruginosae isolated in BSIs are shown in Table 8. 
Table 8. Pseudomonas aeruginosa isolates from bloodstream infections' resistance profiles.

\begin{tabular}{|c|c|c|c|c|c|c|c|c|c|c|c|c|}
\hline \multirow{2}{*}{ Agent } & \multirow{2}{*}{ MIC50 } & \multirow{2}{*}{ MIC90 } & \multirow{2}{*}{ Range } & \multirow{2}{*}{ Count } & \multicolumn{4}{|c|}{ CLSI $^{a}$} & \multicolumn{4}{|c|}{ EUCAST $^{a}$} \\
\hline & & & & & $\% \mathrm{~S}$ & $\% \mathbf{I}$ & $\% R$ & Count & $\% \mathrm{~S}$ & $\% \mathbf{I}$ & $\% R$ & Count \\
\hline Amikacin & 4 & 16 & $\leq 0.25$ to $>32$ & 3264 & 92.6 & 1.5 & 5.9 & 3264 & 92.6 & & $7.4^{b}$ & 3264 \\
\hline Gentamicin & 2 & $>8$ & $\leq 1$ to $>8$ & 3264 & 86.0 & 3.5 & 10.5 & 3264 & & & & \\
\hline Tobramycin & 0.5 & $>8$ & $\leq \overline{0} .12$ to $>8$ & 3264 & 88.8 & 0.6 & 10.6 & 3264 & 88.4 & & $11.6^{\mathrm{b}}$ & 3264 \\
\hline $\begin{array}{l}\text { Ampicillin- } \\
\text { sulbactam }\end{array}$ & $>32$ & $>32$ & 4 to $>32$ & 3264 & & & & & & & & \\
\hline $\begin{array}{l}\text { Cefoperazone- } \\
\text { sulbactam }\end{array}$ & 4 & $>32$ & $\leq 1$ to $>32$ & 2743 & & & & & & & & \\
\hline $\begin{array}{l}\text { Ceftazidime- } \\
\text { avibactam }\end{array}$ & 2 & 8 & 0.25 to $>32$ & 428 & 93.9 & & 6.1 & 428 & 93.9 & & 6.1 & 428 \\
\hline $\begin{array}{l}\text { Ceftolozane- } \\
\text { tazobactam }\end{array}$ & 0.5 & 2 & $\leq 0.12$ to $>16$ & 435 & 93.8 & 0.9 & 5.3 & 435 & 93.8 & & 6.2 & 435 \\
\hline $\begin{array}{l}\text { Piperacillin- } \\
\text { tazobactam }\end{array}$ & 4 & $>64$ & $\leq 0.5$ to $>64$ & 3259 & 79.3 & 10.0 & 10.7 & 3259 & & & & \\
\hline Doripenem & 0.5 & $>4$ & $\leq 0.12$ to $>4$ & 2827 & 80.3 & 6.0 & 13.7 & 2827 & & & & \\
\hline Imipenem & 1 & $>8$ & $\leq 0.12$ to $>8$ & 3264 & 75.6 & 3.8 & 20.6 & 3264 & & & & \\
\hline Meropenem & 0.5 & $>8$ & $\leq 0.06$ to $>8$ & 3254 & 78.4 & 5.3 & 16.3 & 3254 & $\begin{array}{l}78.4 \\
78.4\end{array}$ & 10.1 & $\begin{array}{l}21.6^{\mathrm{c}} \\
11.4^{\mathrm{d}}\end{array}$ & $\begin{array}{l}3254 \\
3254\end{array}$ \\
\hline Cefepime & 2 & 16 & $\leq 0.5$ to $>16$ & 3256 & 83.5 & 8.9 & 7.6 & 3256 & & & & \\
\hline Cefoperazone & 8 & $>32$ & $\overline{0} .25$ to $>32$ & 768 & & & & & & & & \\
\hline Ceftazidime & 2 & $>16$ & $\leq 0.25$ to $>16$ & 3257 & 81.1 & 4.4 & 14.5 & 3257 & & & & \\
\hline $\begin{array}{l}\text { Trimethoprim- } \\
\text { sulfamethoxazole }\end{array}$ & 4 & $>4$ & $\leq 0.5$ to $>4$ & 3257 & & & & & & & & \\
\hline Colistin & 1 & 2 & $\leq 0.5$ to $>8$ & 3264 & & & & & 99.3 & & 0.7 & 3264 \\
\hline Polymyxin B & 2 & 2 & $\leq 0.25$ to 4 & 937 & & & & & & & & \\
\hline Aztreonam & 8 & $>16$ & 0.25 to $>16$ & 3257 & 70.3 & 11.8 & 17.8 & 3257 & & & & \\
\hline Ciprofloxacin & 0.12 & $>4$ & $\leq 0.03$ to $>4$ & 3259 & 76.5 & 3.5 & 20.0 & 3259 & & & & \\
\hline Levofloxacin & 0.5 & $>4$ & $\leq 0.12$ to $>4$ & 3253 & 69.9 & 7.3 & 22.8 & 3253 & & & & \\
\hline Moxifloxacin & 1 & $>4$ & $\leq 0.25$ to $>4$ & 2626 & & & & & & & & \\
\hline Minocycline & $>8$ & $>8$ & 0.25 to $>8$ & 3164 & & & & & & & & \\
\hline
\end{tabular}

${ }^{a}$ Criteria as published by CLSI (2021) and EUCAST (2021). ${ }^{\mathrm{b}}$ For infections originating from the urinary tract. For systemic infections, aminoglycosides must be used in combination with other active therapy. ${ }^{\mathrm{c}}$ Using meningitis breakpoints. ${ }^{\mathrm{d}}$ Using non-meningitis breakpoints. Organisms included: Pseudomonas aeruginosa (3264). Report generated using MVP (https://sentry-mvp.jmilabs.com, assessed on 4 June 2021), a product of JMI Laboratories, on 5 June 2021 11:13:28 GMT/UTC. The data and information are available in the SENTRY Antimicrobial Surveillance Program dataset.

\subsection{Enterobacter spp.}

Enterobacter spp. are facultative, anaerobic, motile Gram-negative bacteria. There are normally commensals present in the gut of man, but they can cause infections in immunosuppressed or hospitalized subjects. Many strains exhibit numerous resistance mechanisms, such as extended-spectrum beta-lactamase, metallo-beta-lactamase and carbapenemases, which confer resistance to almost all antibiotics except tigecycline and colistin [28]. The resistance profiles of strains of Enterobater spp. isolated in BSIs are shown in Table 9. 
Table 9. Enterobacter spp. isolates from bloodstream infections' resistance profiles.

\begin{tabular}{|c|c|c|c|c|c|c|c|c|c|c|c|c|}
\hline \multirow{2}{*}{ Agent } & \multirow{2}{*}{ MIC50 } & \multirow{2}{*}{ MIC90 } & \multirow{2}{*}{ Range } & \multirow{2}{*}{ Count } & \multicolumn{4}{|c|}{ CLSI $^{a}$} & \multicolumn{4}{|c|}{ EUCAST $^{a}$} \\
\hline & & & & & $\% \mathrm{~S}$ & $\% \mathbf{I}$ & $\% R$ & Count & $\% \mathrm{~S}$ & $\% \mathbf{I}$ & $\% R$ & Count \\
\hline Amikacin & 1 & 2 & $\leq 0.25$ to $>32$ & 2239 & 98.6 & 0.3 & 1.1 & 2239 & 97.9 & & $2.1^{\mathrm{b}}$ & 2239 \\
\hline Gentamicin & $\leq 1$ & $\leq 1$ & $\leq 1$ to $>8$ & 2241 & 92.5 & 0.8 & 6.7 & 2241 & 91.7 & & $8.3^{b}$ & 2241 \\
\hline Tobramycin & $\overline{0.5}$ & $\overline{4}$ & $\leq \overline{0} .12$ to $>8$ & 2238 & 90.9 & 1.9 & 7.2 & 2238 & 89.6 & & $10.4^{b}$ & 2238 \\
\hline $\begin{array}{l}\text { Amoxicillin- } \\
\text { clavulanic } \\
\text { acid }\end{array}$ & $>8$ & $>8$ & $\leq 1$ to $>8$ & 1451 & 3.3 & 1.4 & 57.5 & 1451 & & & & \\
\hline $\begin{array}{l}\text { Ampicillin- } \\
\text { sulbactam }\end{array}$ & 32 & $>32$ & 0.5 to $>32$ & 2233 & 17.2 & 20.1 & 62.7 & 2233 & 17.2 & & $82.8^{c}$ & 2233 \\
\hline $\begin{array}{l}\text { Cefoperazone- } \\
\text { sulbactam }\end{array}$ & 0.5 & 16 & $\leq 0.25$ to $>32$ & 1853 & 82.6 & & $17.4^{\mathrm{d}}$ & 1853 & & & & \\
\hline $\begin{array}{l}\text { Ceftazidime- } \\
\text { avibactam }\end{array}$ & 0.25 & 0.5 & 0.03 to 32 & 337 & 99.7 & & 0.3 & 337 & 99.7 & & 0.3 & 337 \\
\hline $\begin{array}{l}\text { Ceftolozane- } \\
\text { tazobactam }\end{array}$ & 0.25 & 8 & $\leq 0.12$ to $>16$ & 337 & 84.3 & 3.0 & 12.8 & 337 & 84.3 & & 15.7 & 337 \\
\hline $\begin{array}{l}\text { Piperacillin- } \\
\text { tazobactam }\end{array}$ & 2 & 64 & $\leq 0.5$ to $>64$ & 2237 & 81.1 & 9.8 & 9.1 & 2237 & 77.2 & & 22.8 & 2237 \\
\hline Doripenem & $\leq 0.12$ & $\leq 0.12$ & $\leq 0.12$ to $>4$ & 1903 & 98.1 & 0.5 & 1.4 & 1903 & 98.1 & 0.5 & 1.4 & 1903 \\
\hline Ertapenem & 0.06 & 0.5 & $\leq 0.008$ to $>2$ & 883 & 90.8 & 4.5 & 4.6 & 883 & 90.8 & & 9.2 & 883 \\
\hline Imipenem & 0.25 & 1 & $\leq 0.12$ to $>8$ & 2240 & 97.8 & 0.8 & 1.4 & 2240 & 98.6 & 0.4 & 1.0 & 2240 \\
\hline Meropenem & $\leq 0.06$ & 0.12 & $\leq 0.06$ to $>8$ & 2240 & 98.3 & 0.3 & 1.4 & 2240 & $\begin{array}{l}98.6 \\
98.6\end{array}$ & 0.7 & $\begin{array}{l}1.4^{\mathrm{e}} \\
0.7^{\mathrm{f}}\end{array}$ & $\begin{array}{l}2240 \\
2240\end{array}$ \\
\hline Cefepime & $\leq 0.5$ & 4 & $\leq 0.5$ to $>16$ & 2238 & 88.8 & 4.3 & $6.9^{g}$ & 2238 & 83.1 & 8.5 & 8.4 & 2238 \\
\hline Cefoperazone & 0.5 & $>32$ & $\leq 0.25$ to $>32$ & 471 & 76.2 & 1.9 & $21.9^{\mathrm{d}}$ & 471 & & & & \\
\hline Cefoxitin & $>16$ & $>16$ & 2 to $>16$ & 286 & 3.1 & 1.7 & 95.1 & 286 & & & & \\
\hline Ceftaroline & 0.25 & $>16$ & $\leq 0.03$ to $>16$ & 2200 & 66.4 & 3.7 & 29.9 & 2200 & 66.4 & & 33.6 & 2200 \\
\hline Ceftazidime & 0.5 & $>16$ & $\leq 0.12$ to $>16$ & 2241 & 73.6 & 1.1 & 25.3 & 2241 & 69.8 & 3.7 & 26.4 & 2241 \\
\hline Ceftriaxone & 0.25 & $>8$ & $\leq 0.06$ to $>8$ & 2219 & 68.4 & 1.5 & 30.1 & 2219 & $\begin{array}{l}68.4 \\
68.4\end{array}$ & 1.5 & $\begin{array}{l}31.6^{\mathrm{e}} \\
30.1^{\mathrm{f}}\end{array}$ & $\begin{array}{l}2219 \\
2219\end{array}$ \\
\hline Cefuroxime & 16 & $>64$ & 0.5 to $>64$ & 646 & $\begin{array}{l}12.7 \\
43.5\end{array}$ & $\begin{array}{l}44.4 \\
13.6\end{array}$ & $\begin{array}{l}42.9^{h} \\
42.9^{i}\end{array}$ & $\begin{array}{l}646 \\
646\end{array}$ & & & & \\
\hline $\begin{array}{l}\text { Trimethoprim- } \\
\text { sulfamethoxazole }\end{array}$ & $\leq 0.5$ & $>4$ & $\leq 0.5$ to $>4$ & 2237 & 84.4 & & 15.6 & 2237 & 84.4 & 0.2 & 15.4 & 2237 \\
\hline Tigecycline & 0.5 & 1 & $\leq 0.06$ to $>8$ & 2240 & 98.6 & 1.4 & $0.1^{j}$ & 2240 & & & & \\
\hline Colistin & $\leq 0.5$ & $>8$ & $\leq 0.5$ to $>8$ & 2166 & & & & & 78.8 & & 21.2 & 2166 \\
\hline Polymyxin B & 1 & $>8$ & $\leq 0.25$ to $>8$ & 539 & & & & & & & & \\
\hline Aztreonam & $\leq 0.12$ & $>16$ & $\leq 0.12$ to $>16$ & 2235 & 74.0 & 1.7 & 24.3 & 2235 & 71.5 & 2.5 & 26.0 & 2235 \\
\hline Ciprofloxacin & $\leq 0.03$ & 1 & $\leq 0.03$ to $>4$ & 2235 & 85.7 & 3.1 & 11.2 & 2235 & 85.7 & 3.1 & 11.2 & 2235 \\
\hline Levofloxacin & $\leq 0.12$ & 1 & $\leq 0.12$ to $>4$ & 2237 & 89.4 & 2.5 & 8.2 & 2237 & 89.4 & 2.5 & 8.2 & 2237 \\
\hline Moxifloxacin & $\leq 0.25$ & 2 & $\leq 0.25$ to $>4$ & 1732 & & & & & 79.3 & & 20.7 & 1732 \\
\hline Doxycycline & 2 & 8 & $\leq 0.06$ to $>8$ & 2039 & 87.7 & 5.2 & 7.0 & 2039 & & & & \\
\hline Minocycline & 2 & 8 & 0.25 to $>8$ & 2057 & 88.9 & 4.8 & 6.3 & 2057 & & & & \\
\hline Tetracycline & 2 & $>8$ & $\leq 0.5$ to $>8$ & 2069 & 85.1 & 3.2 & 11.7 & 2069 & & & & \\
\hline
\end{tabular}

${ }^{a}$ Criteria as published by CLSI (2021) and EUCAST (2021). ${ }^{b}$ For infections originating from the urinary tract. For systemic infections, aminoglycosides must be used in combination with other active therapy. ${ }^{\mathrm{c}}$ These breakpoints for oral administration are relevant for uncomplicated urinary tract infections only. ${ }^{\mathrm{d}}$ The cefoperazone breakpoints were applied following US FDA criteria. ${ }^{\mathrm{e}}$ Using meningitis breakpoints. ${ }^{\mathrm{f}}$ Using non-meningitis breakpoints. ${ }^{\mathrm{g}}$ Intermediate is interpreted as susceptible-dose dependent. ${ }^{\mathrm{h}}$ Using oral breakpoints. ${ }^{\mathrm{i}}$ Using parenteral breakpoints. ${ }^{j}$ US FDA breakpoints were applied. Organisms included: Enterobacter asburiae (21), E. cancerogenus (2), E. cloacae (1182), E. cloacae species complex (1027), E. hormaechei (3), E. intermedius (1), and E. kobei (5). Report generated using MVP (https:/ / sentry-mvp.jmilabs.com accessed on 4 June 2021), a product of JMI Laboratories, on 5 June 2021 11:14:36 GMT/UTC. The data and information are available in the SENTRY Antimicrobial Surveillance Program dataset.

\section{Risk Factors}

Due to the increased interest during recent years on the topic of ICU-BSIs, several risk factors have been defined that may be used to promptly recognize and treat susceptible patients. The APACHE II score (Acute Physiologic Assessment and Chronic Health Evaluation II score), prolonged in-hospital stay, need for mechanical ventilation, renal replacement therapy, immunosuppression, compromised liver functionality, surgery, invasive procedures, and acquired infections have been identified as the main risk factors for BSIs [29].

Among acquired infections, it has recently been demonstrated that even the COVID-19 disease is strictly related to poor outcomes in hospitalized patients, predisposing patient 
to infection by MDR in-hospital pathogens with low survival rates even though there is currently no therapy for COVID-19 infection whose efficacy has been proven [30,31].

The risk factors are listed in Figure 1.

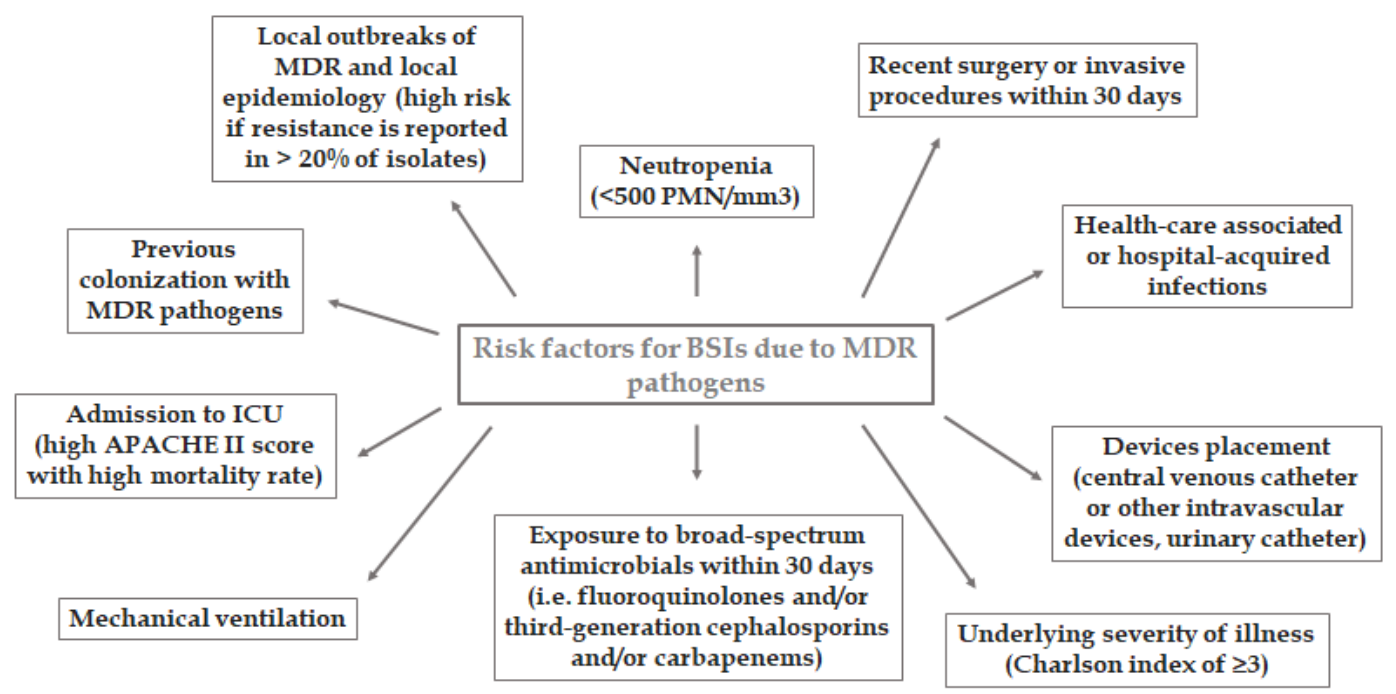

Figure 1. Risk factors for BSIs due to MDR pathogens.

According to the EUROBACT-1 international study that enrolled 1156 ICU-acquired BSIs, $21 \%$ of infections originated from venous catheters (catheter-related BSIs (CR-BSIs)), $21 \%$ were form nosocomial pneumonia (ventilator associated pneumonia (VAP)) (which is a frequent complication when mechanical ventilation is required), $24 \%$ of episodes were due to intra-abdominal infections, and another $24 \%$ had no definite source [10].

The diagnosis of CR-BSIs is provided by the identification of the same microbiological pathogen from both peripheral blood cultures and from the culture of the venous catheter tips. CR-BSIs are among the most frequently encountered BSIs in ICU patients, along with BSIs related to VAP and/or to abdominal infections, including the development from the urinary tract [29].

\section{Early Microbiological Diagnosis in BSI}

Even if culture methods represent the best choice for detecting an infection, the methodology based on molecular assays is achieving remarkable results in terms of specificity and execution times. In the context of sepsis, in fact, timing is crucial and antibiotic therapy should be changed abruptly based on laboratory results. Molecular assays offer rapid results on blood samples without prior incubation. These new techniques are able to determine pathogens and related resistances but, unfortunately, still show a medium sensitivity for pathogens and have a limited number of antibiotic resistances [32];

Besides, a prompt initiation of empirical antimicrobial therapy may be the only chance for a septic patient, but may also significantly reduce the sensitivity of blood cultures drawn, even shortly after treatment initiation [33].

The choice of antimicrobial agent for empirical therapy must take into account several factors such as: the type of pathogen suspected of being involved, any suspicion of resistance or the onset of fungal infection [34,35].

Leukopenia and immunosuppression are other factors to consider because they increase the risk of MDR and fungal infections [36].

Recently, new magnetic resonance-based tests have been introduced that show good sensitivity and short execution times (T2Bacteria Panel, T2Biosystems) [37].

Other very promising, but in development, methods to obtain quickly an etiological accurate diagnosis are next-generation sequencing (NGS) and application of machinelearning [38-40]. 
These techniques may effectively improve treatment optimization in the ICU, reducing the percentage of empirically treated infections [36], anticipating the timing of de-escalation treatment, and improving critically ills patients' outcomes [41].

In this scenario, a thrifty use of recently approved drugs active against MDR organisms is fundamental. The objective of treatment should be to promptly administrate an effective treatment, not improving the selection of antimicrobial resistance using the most recent and high spectrum drugs indiscriminately [42]. Therefore, the prevalence of carbapenemases in each clinical environment should now be taken into account when prompting empirical therapies. The availability of novel beta-lactams/beta-lactamases inhibitor (BL-BLI) combinations, active against MDR Gram-negative bacteria expressing different determinants of resistance, is already changing the approach to management of septic patients [43].

\section{Rationale of Treatment}

\subsection{Single-Drug or Combination Therapy for Bloodstream Infection in ICU Patients}

Nowadays, in the case of a patient with a diagnosis of a blood stream infection the primary object when planning a first line empirical treatment regimen is to combine multiple antimicrobial molecules to maximize the likelihood of efficacy against the hypothesized pathogen due to the high rates of antimicrobial resistance. Usually, the associations of antimicrobials include a beta-lactam plus an aminoglycoside or a beta-lactam plus a fluoroquinolone. However, once the pathogen responsible of the infection has been identified and the profile of resistance detected, the choice of whether to continue with an association therapeutic regime or to switch to a targeted regime with a single antimicrobial is arbitrary, and little and conflicting evidence has been made available to date. According to experimental models, antimicrobial combination can prevent or postpone the selection of resistant species. The synergistic action of several antibiotics has to be exploited in case of BSIs by P. aeruginosae and/or other non-fermenting Gram-negative pathogens [44]. The lack of clinical reports confirming the data collected from in vitro models leaves unsettled the utility of combination therapy to prevent antimicrobial resistance development. Furthermore, numerous studies and meta-analyses were not able to demonstrate that the association of beta-lactam and aminoglycosides or fluoroquinolones in comparison to beta-lactam monotherapy can reduce fatality rates in patients, including those with sepsis or neutropenia [45]. Moreover, in a regimen that uses a beta-lactam antibiotic, the introduction of an aminoglycoside has frequently increased the rate of acute renal failure in the acute phase of infection $[45,46]$.

Even on a pathogen-specific analysis, in the case of BSI due to methicillin-susceptible $S$. aureus (except in those with implanted devices) or Enterobacterales, including AmpChyperproducers and ESBL-PE, there is poor data to demonstrate that a double antimicrobial regimen favorably impacts patient outcomes [1].

In the case of carbapenem-resistant A. baumanni, a polymyxin-based combination may perform better than polymyxin alone only when a high-dose colistin regimen is administered.

Concerning BSIs caused by $P$. aeruginosae, strong doubts as to the advantages of combination therapy persist, because no rise in survival rates has been detected yet [1].

Recently, two systematic reviews evaluated combination therapy based on CeftolozaneTazobactam or Ceftazidime-Avibactam compared to monotherapies for the Treatment of Severe BSIs [47].

In conclusion, combination therapy is still an indicated approach for patients with septic shock, but should not be prescribed as routine treatment. Conditions other than severe infections, including sepsis without circulatory failure, may not benefit from antimicrobial combination but may suffer from cumulative side effects [26]. 


\subsection{De-Escalation Strategy}

In the contest of antimicrobial stewardship strategies (AMS), antimicrobial de-escalation (ADE) is a strategy that aims to reduce the spectrum of the chosen antibiotic, narrowing its spectrum but not reducing treatment efficacy, and to decrease the emergence of antimicrobial resistance-even reducing the number of antimicrobials involved in treatment [48]. The ADE should be started 2-3 days after diagnosis of an infection; with the availability of microbiological specimens, the re-evaluation of antimicrobial regimens can be performed. Considering that in all BSIs, the pathogen or the pathogens are always known, these infections are perfect candidates for re-evaluation. According to ADE strategy, the source and the pathogen responsible of the BSI are isolated, and it is strictly recommended, even in immunocompromised patients [49], to stop broad spectrum combination therapy and to re-evaluate the treatment regimen. For example, in case of a diagnosis of a Gram-negative BSI, anti-MRSA or antifungal agents should be suspended because their administration has been proven to be ineffective.

In the case of $\mathrm{ADE}$, regarding the antibiotic chosen empirically as a first line molecule, the management will be more complex due to multiple factors.

The antibiotics' spectrum of action is variable according to the region of the world, and the ranking depends on the priorities that are considered [50].

The period of in-hospital stay and the comorbidities of the patient are factors that surely will influence the development of antimicrobial resistance. The employment of ADE usually lengthens the duration of antimicrobial therapy [51]. Since multiple recent studies on different sources of infection have recommended a shorter duration of antimicrobial therapy as a target of treatment because longer exposure to antimicrobials predisposes one to the development of MDR pathogens [52].

Sometimes the switching from beta-lactam to oral fluoroquinolones may be useful at ward dismissal to reduce in-hospital patient stay, but this strategy may not be so useful in the ICU due to the high rate of resistance that has emerged from using those therapeutic regimens.

Carbapenems are the most used antimicrobials in ICU therapeutics regimens, however the incidence of resistance has increased, especially in the case of long course treatment and, unfortunately, most pathogens that have become endemic in ICUs have developed multiple resistance mechanisms to this class of antimicrobials, therefore MDR pathogens have been found even after only 1-3 days of in-ICU therapy [53]. According to what was said before about the early development of resistance, this renders ADE useless.

In some cases, another factor that influences antimicrobial management is patients' antimicrobial flora, which may conditionate the emergence of resistance and the response to treatment [54].

In the case of polymicrobial infections (i.e., intra-abdominal infections), it is important to be cautious because not all pathogens are evidenced by blood cultures, and drugs not continued according to ADE may have been required.

Using in silico pharmacokinetic-pharmacodynamic (PK/PD) modeling, it has been shown that the conventional dosing strategy of using a narrow spectrum beta-lactam may have higher risks of not attaining the target compared to broad spectrum regimens [55].

Furthermore, it must be considered that some narrower spectrum alternatives are sometimes more effective than broad-spectrum regimens (i.e., oxacillin or cephazolin are superior to piperacillin/tazobactam in S. aureus BSIs) [56].

It is strictly recommended that one consider all the points described above before deciding whether narrowing the first line antimicrobial is the adequate decision to take in the case of BSIs in critically ill patients. The ADE is spreading among clinicians as a main part of the global AMS re-evaluation plan, with the objective of the optimization of the treatment in patients with a severe infection. The ADE consent to adapt antimicrobial treatment of BSIs every time the laboratory data elaboration provides new information on the profile of the pathogens that are the cause of infections. 


\section{Conclusions}

BSIs are frequent conditions that need to be diagnosed and treated in ICUs and in-hospital patients. BSIs are associated with impaired outcomes, especially in the case of sepsis/septic shock, immune deficiency, and delayed adequate antimicrobial therapy. Among severely ill patients, the prevalence of MDR pathogens is higher when compared to other classes of hospitalized patients. The increase in healthcare related BSIs due to MDR pathogens may stress the need for innovative diagnostic tools that can improve the fast and accurate identification of resistance markers.

While waiting for such data, the choice regarding the best empirical regimen to be promptly adopted depends on many clinical parameters, including the patient's individual risk factors, individual predisposition to MDR infections, and the geographical pathogen distribution.

Combination therapy might be a solution capable of improving survival rates in the most severely ill patients, even if further data need to be collected and analyzed to validate this theory. Once culture results become available, the source of a BSI is identified and well controlled, antimicrobial de-escalation can be performed, and treatment duration can be shortened as much as possible. Longer treatments may be proposed only in specific clinical scenarios such as BSI due to $S$. aureus.

Author Contributions: Conceptualization, S.D.F., A.A. and M.B.P.; methodology, A.A. and M.F.; software, A.A. and S.D.F.; validation, V.P., C.F., M.C.P. and P.S.; formal analysis, A.A. and S.D.F.; investigation, A.A. and S.D.F.; resources, M.B.P.; data curation, A.A. and S.D.F.; writing-original draft preparation, A.A. and S.D.F.; writing-review and editing, A.A. and S.D.F.; visualization, V.P., C.F., M.C.P. and P.S.; supervision, M.B.P. All authors have read and agreed to the published version of the manuscript.

Funding: This research received no external funding.

Institutional Review Board Statement: Not applicable.

Informed Consent Statement: Not applicable.

Conflicts of Interest: The authors declare no conflict of interest. 


\section{Appendix A}

Table A1. Search Strings.

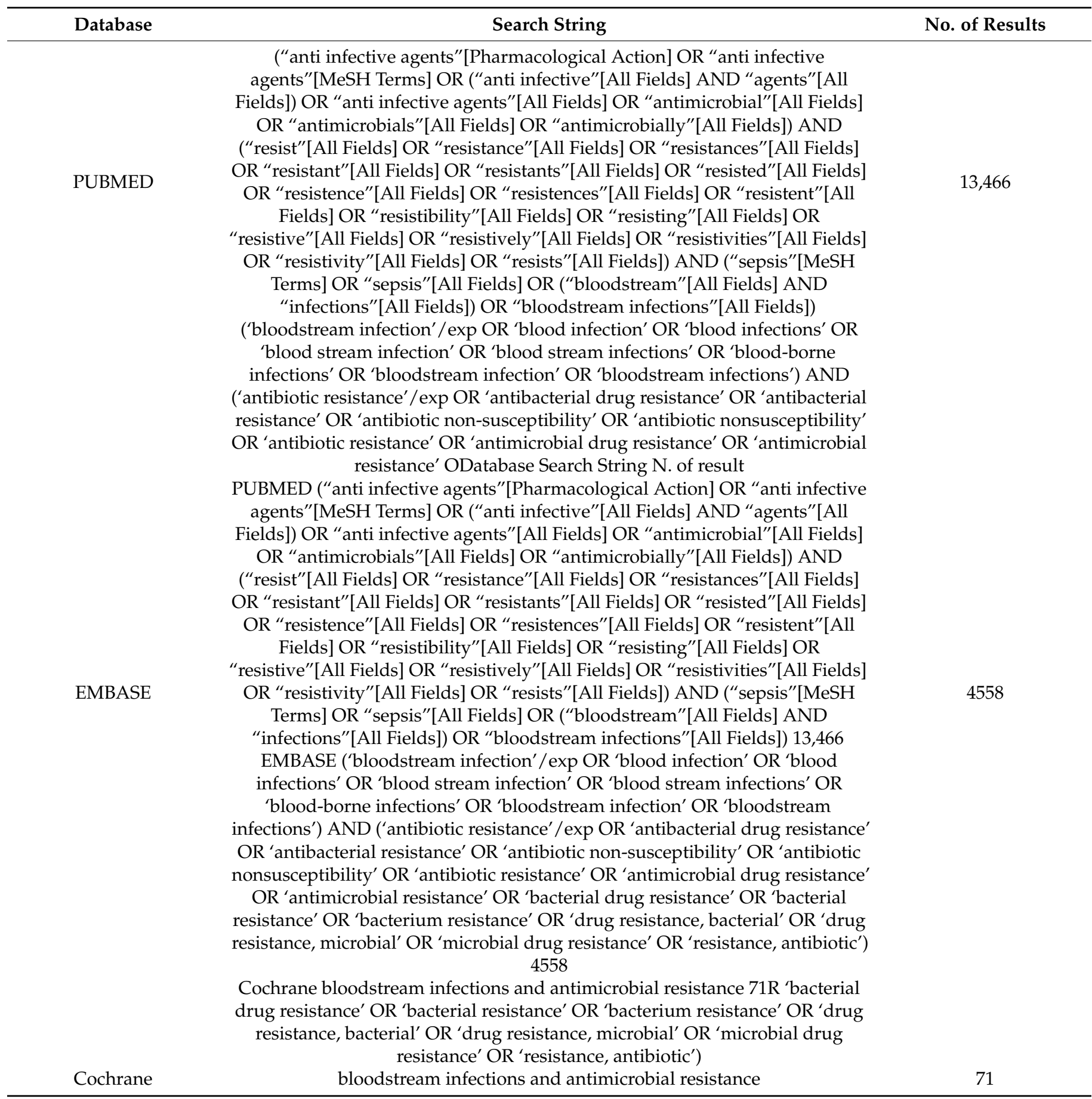

\section{References}

1. Timsit, J.F.; Ruppe, E.; Barbier, F.; Tabah, A.; Bassetti, M. Bloodstream infections in critically ill patients: An expert statement. Intensive Care Med. 2020, 46, 266-284. [CrossRef] [PubMed]

2. Adrie, C.; Garrouste-Orgeas, M.; Ibn Essaied, W.; Schwebel, C.; Darmon, M.; Mourvillier, B.; Ruckly, S.; Dumenil, A.S.; Kallel, H.; Argaud, L.; et al. Attributable mortality of ICU-acquired bloodstream infections: Impact of the source, causative microorganism, resistance profile and antimicrobial therapy. J. Infect. 2017, 74, 131-141. [CrossRef] [PubMed]

3. Bartoletti, M.; Giannella, M.; Caraceni, P.; Domenicali, M.; Ambretti, S.; Tedeschi, S.; Verucchi, G.; Badia, L.; Lewis, R.E.; Bernardi, M.; et al. Epidemiology and outcomes of bloodstream infection in patients with cirrhosis. J. Hepatol. 2014, 61, 51-58. [CrossRef] 
4. Islas-Munoz, B.; Volkow-Fernandez, P.; Ibanes-Gutierrez, C.; Villamar-Ramirez, A.; Vilar-Compte, D.; Cornejo-Juarez, P. Bloodstream infections in cancer patients. Risk factors associated with mortality. Int. J. Infect. Dis. 2018, 71, 59-64. [CrossRef] [PubMed]

5. Silva, M., Jr.; Marra, A.R.; Pereira, C.A.; Medina-Pestana, J.O.; Camargo, L.F. Bloodstream infection after kidney transplantation: Epidemiology, microbiology, associated risk factors, and outcome. Transplantation 2010, 90, 581-587. [CrossRef] [PubMed]

6. Bassetti, M.; Righi, E.; Carnelutti, A. Bloodstream infections in the Intensive Care Unit. Virulence 2016, 7, 267-279. [CrossRef] [PubMed]

7. Santoro, A.; Franceschini, E.; Meschiari, M.; Menozzi, M.; Zona, S.; Venturelli, C.; Digaetano, M.; Rogati, C.; Guaraldi, G.; Paul, M.; et al. Epidemiology and Risk Factors Associated with Mortality in Consecutive Patients with Bacterial Bloodstream Infection: Impact of MDR and XDR Bacteria. Open Forum Infect. Dis. 2020, 7, ofaa461. [CrossRef]

8. Singer, M.; Deutschman, C.S.; Seymour, C.W.; Shankar-Hari, M.; Annane, D.; Bauer, M.; Bellomo, R.; Bernard, G.R.; Chiche, J.D.; Coopersmith, C.M.; et al. The Third International Consensus Definitions for Sepsis and Septic Shock (Sepsis-3). JAMA 2016, 315, 801-810. [CrossRef]

9. Laupland, K.B.; Church, D.L. Population-based epidemiology and microbiology of community-onset bloodstream infections Clin. Microbiol. Rev. 2014, 27, 647-664. [CrossRef] [PubMed]

10. Tabah, A.; Koulenti, D.; Laupland, K.; Misset, B.; Valles, J.; Bruzzi de Carvalho, F.; Paiva, J.A.; Cakar, N.; Ma, X.; Eggimann, P.; et al. Characteristics and determinants of outcome of hospital-acquired bloodstream infections in intensive care units: The EUROBACT International Cohort Study. Intensive Care Med. 2012, 38, 1930-1945. [CrossRef]

11. Corona, A.; Bertolini, G.; Lipman, J.; Wilson, A.P.; Singer, M. Antibiotic use and impact on outcome from bacteraemic critical illness: The Bacteraemia Study in Intensive Care (BASIC). J. Antimicrob. Chemother. 2010, 65, 1276-1285. [CrossRef]

12. Diekema, D.J.; Hsueh, P.R.; Mendes, R.E.; Pfaller, M.A.; Rolston, K.V.; Sader, H.S.; Jones, R.N. The Microbiology of Bloodstream Infection: 20-Year Trends from the SENTRY Antimicrobial Surveillance Program. Antimicrob. Agents Chemother. 2019, 63. [CrossRef]

13. Li, X.Z.; Nikaido, H. Efflux-mediated drug resistance in bacteria. Drugs 2004, 64, 159-204. [CrossRef] [PubMed]

14. Wright, G.D. Bacterial resistance to antibiotics: Enzymatic degradation and modification. Adv. Drug Deliv. Rev. 2005, 57, 1451-1470. [CrossRef] [PubMed]

15. Wilson, D.N. Ribosome-targeting antibiotics and mechanisms of bacterial resistance. Nat. Rev. Microbiol. 2014, 12, 35-48. [CrossRef] [PubMed]

16. Elsner, H.A.; Sobottka, I.; Mack, D.; Claussen, M.; Laufs, R.; Wirth, R. Virulence factors of Enterococcus faecalis and Enterococcus faecium blood culture isolates. Eur. J. Clin. Microbiol. Infect. Dis. 2000, 19, 39-42. [CrossRef] [PubMed]

17. Denyer, S.P.; Hodges, N.A.; Gorman, S.P. Hugo and Russell's Pharmaceutical Microbiology; John Wiley \& Sons: Hoboken, NJ, USA, 2008.

18. Hope, R.; Livermore, D.M.; Brick, G.; Lillie, M.; Reynolds, R. On Behalf of BSAC Working Parties on Resistance Surveillance Non-susceptibility trends among staphylococci from bacteraemias in the UK and Ireland, 2001. J. Antimicrob. Chemother. 2008, 62 (Suppl. 2), ii65-ii74. [CrossRef]

19. Wu, D.; Wang, Q.; Yang, Y.; Geng, W.; Wang, Q.; Yu, S.; Yao, K.; Yuan, L.; Shen, X. Epidemiology and molecular characteristics of community-associated methicillin-resistant and methicillin-susceptible Staphylococcus aureus from skin/soft tissue infections in a children's hospital in Beijing, China. Diagn. Microbiol. Infect. Dis. 2010, 67, 1-8. [CrossRef]

20. Chambers, H.F.; Deleo, F.R. Waves of resistance: Staphylococcus aureus in the antibiotic era. Nat. Rev. Microbiol. $2009,7,629-641$. [CrossRef]

21. Appelbaum, P.C. Reduced glycopeptide susceptibility in methicillin-resistant Staphylococcus aureus (MRSA). Int. J. Antimicrob. Agents 2007, 30, 398-408. [CrossRef] [PubMed]

22. Queenan, A.M.; Bush, K. Carbapenemases: The versatile beta-lactamases. Clin. Microbiol. Rev. 2007, 20, 440-458. [CrossRef] [PubMed]

23. Yong, D.; Toleman, M.A.; Giske, C.G.; Cho, H.S.; Sundman, K.; Lee, K.; Walsh, T.R. Characterization of a new metallo-betalactamase gene, bla(NDM-1), and a novel erythromycin esterase gene carried on a unique genetic structure in Klebsiella pneumoniae sequence type 14 from India. Antimicrob. Agents Chemother. 2009, 53, 5046-5054. [CrossRef] [PubMed]

24. Houang, E.T.; Sormunen, R.T.; Lai, L.; Chan, C.Y.; Leong, A.S. Effect of desiccation on the ultrastructural appearances of Acinetobacter baumannii and Acinetobacter lwoffii. J. Clin. Pathol. 1998, 51, 786-788. [CrossRef] [PubMed]

25. Biendo, M.; Laurans, G.; Lefebvre, J.; Daoudi, F.; Eb, F. Epidemiological study of an Acinetobacter baumannii outbreak by using a combination of antibiotyping and ribotyping. J. Clin. Microbiol. 1999, 37, 2170-2175. [CrossRef]

26. Boucher, H.W.; Talbot, G.H.; Bradley, J.S.; Edwards, J.E.; Gilbert, D.; Rice, L.B.; Scheld, M.; Spellberg, B.; Bartlett, J. Bad bugs, no drugs: No ESKAPE! An update from the Infectious Diseases Society of America. Clin. Infect. Dis. 2009, 48, 1-12. [CrossRef]

27. Bush, K.; Jacoby, G.A.; Medeiros, A.A. A functional classification scheme for beta-lactamases and its correlation with molecular structure. Antimicrob. Agents Chemother. 1995, 39, 1211-1233. [CrossRef]

28. Castanheira, M.; Deshpande, L.M.; Mathai, D.; Bell, J.M.; Jones, R.N.; Mendes, R.E. Early dissemination of NDM-1- and OXA-181producing Enterobacteriaceae in Indian hospitals: Report from the SENTRY Antimicrobial Surveillance Program, $2006-2007$. Antimicrob. Agents Chemother. 2011, 55, 1274-1278. [CrossRef] 
29. Prowle, J.R.; Echeverri, J.E.; Ligabo, E.V.; Sherry, N.; Taori, G.C.; Crozier, T.M.; Hart, G.K.; Korman, T.M.; Mayall, B.C.; Johnson, P.D.; et al. Acquired bloodstream infection in the intensive care unit: Incidence and attributable mortality. Crit. Care 2011, 15, R100. [CrossRef]

30. Giacobbe, D.R.; Battaglini, D.; Ball, L.; Brunetti, I.; Bruzzone, B.; Codda, G.; Crea, F.; de Maria, A.; Dentone, C.; di Biagio, A.; et al. Bloodstream infections in critically ill patients with COVID-19. Eur. J. Clin. Investig. 2020, 50, e13319. [CrossRef]

31. Di Franco, S.; Alfieri, A.; Petrou, S.; Damiani, G.; Passavanti, M.B.; Pace, M.C.; Leone, S.; Fiore, M. Current status of COVID-19 treatment: An opinion review. World J. Virol. 2020, 9, 27-37. [CrossRef]

32. Rhodes, A.; Evans, L.E.; Alhazzani, W.; Levy, M.M.; Antonelli, M.; Ferrer, R.; Kumar, A.; Sevransky, J.E.; Sprung, C.L.; Nunnally, M.E. Surviving sepsis campaign: International guidelines for management of sepsis and septic shock: 2016. Intensive Care Med. 2017, 43, 304-377. [CrossRef] [PubMed]

33. Cheng, M.P.; Stenstrom, R.; Paquette, K.; Stabler, S.N.; Akhter, M.; Davidson, A.C.; Gavric, M.; Lawandi, A.; Jinah, R.; Saeed, Z.; et al. Blood Culture Results Before and After Antimicrobial Administration in Patients with Severe Manifestations of Sepsis: A Diagnostic Study. Ann. Intern. Med. 2019, 171, 547-554. [CrossRef] [PubMed]

34. Bassetti, M.; Righi, E.; Montravers, P.; Cornely, O.A. What has changed in the treatment of invasive candidiasis? A look at the past 10 years and ahead. J. Antimicrob. Chemother. 2018, 73, i14-i25. [CrossRef] [PubMed]

35. Abbas, M.; Paul, M.; Huttner, A. New and improved? A review of novel antibiotics for Gram-positive bacteria. Clin. Microbiol. Infect. 2017, 23, 697-703. [CrossRef] [PubMed]

36. Schnell, D.; Montlahuc, C.; Bruneel, F.; Resche-Rigon, M.; Kouatchet, A.; Zahar, J.-R.; Darmon, M.; Pene, F.; Lemiale, V.; Rabbat, A. De-escalation of antimicrobial therapy in critically ill hematology patients: A prospective cohort study. Intensive Care Med. 2019, 45, 743-745. [CrossRef]

37. Nguyen, M.H.; Clancy, C.J.; Pasculle, A.W.; Pappas, P.G.; Alangaden, G.; Pankey, G.A.; Schmitt, B.H.; Rasool, A.; Weinstein, M.P.; Widen, R. Performance of the T2Bacteria panel for diagnosing bloodstream infections: A diagnostic accuracy study. Ann. Intern. Med. 2019, 170, 845-852. [CrossRef]

38. Chiu, C.Y.; Miller, S.A. Clinical metagenomics. Nat. Rev. Genet. 2019, 20, 341-355. [CrossRef]

39. Grumaz, S.; Stevens, P.; Grumaz, C.; Decker, S.O.; Weigand, M.A.; Hofer, S.; Brenner, T.; von Haeseler, A.; Sohn, K. Next-generation sequencing diagnostics of bacteremia in septic patients. Genome Med. 2016, 8, 1-13. [CrossRef] [PubMed]

40. Blauwkamp, T.A.; Thair, S.; Rosen, M.J.; Blair, L.; Lindner, M.S.; Vilfan, I.D.; Kawli, T.; Christians, F.C.; Venkatasubrahmanyam, S.; Wall, G.D. Analytical and clinical validation of a microbial cell-free DNA sequencing test for infectious diseases. Nat. Microbiol. 2019, 4, 663-674. [CrossRef]

41. Mangioni, D.; Viaggi, B.; Giani, T.; Arena, F.; D’Arienzo, S.; Forni, S.; Tulli, G.; Rossolini, G.M. Diagnostic stewardship for sepsis: The need for risk stratification to triage patients for fast microbiology workflows. Future Microbiol. 2019. [CrossRef]

42. Tacconelli, E.; Gorska, A.; de Angelis, G.; Lammens, C.; Restuccia, G.; Schrenzel, J.; Huson, D.; Carević, B.; Preoţescu, L.; Carmeli, Y. Estimating the association between antibiotic exposure and colonization with extended-spectrum $\beta$-lactamase-producing Gram-negative bacteria using machine learning methods: A multicentre, prospective cohort study. Clin. Microbiol. Infect. 2020, 26, 87-94. [CrossRef]

43. Giacobbe, D.R.; Mikulska, M.; Viscoli, C. Recent advances in the pharmacological management of infections due to multidrugresistant Gram-negative bacteria. Expert Rev. Clin. Pharmacol. 2018, 11, 1219-1236. [CrossRef]

44. Tamma, P.D.; Cosgrove, S.E.; Maragakis, L.L. Combination therapy for treatment of infections with gram-negative bacteria. Clin. Microbiol. Rev. 2012, 25, 450-470. [CrossRef] [PubMed]

45. Paul, M.; Dickstein, Y.; Schlesinger, A.; Grozinsky-Glasberg, S.; Soares-Weiser, K.; Leibovici, L. Beta-lactam versus beta-lactamaminoglycoside combination therapy in cancer patients with neutropenia. Cochrane Database Syst. Rev. 2013. [CrossRef]

46. Ong, D.S.; Frencken, J.F.; Klein Klouwenberg, P.; Juffermans, N.; van der Poll, T.; Bonten, M.J.; Cremer, O.L. Short-course adjunctive gentamicin as empirical therapy in patients with severe sepsis and septic shock: A prospective observational cohort study. Clin. Infect. Dis. 2017, 64, 1731-1736. [CrossRef] [PubMed]

47. Fiore, M.; Corrente, A.; Pace, M.C.; Alfieri, A.; Simeon, V.; Ippolito, M.; Giarratano, A.; Cortegiani, A. Ceftolozane-Tazobactam Combination Therapy Compared to Ceftolozane-Tazobactam Monotherapy for the Treatment of Severe Infections: A Systematic Review and Meta-Analysis. Antibiotics 2021, 10, 79. [CrossRef] [PubMed]

48. De Waele, J.J.; Akova, M.; Antonelli, M.; Canton, R.; Carlet, J.; De Backer, D.; Dimopoulos, G.; Garnacho-Montero, J.; Kesecioglu, J.; Lipman, J.; et al. Antimicrobial resistance and antibiotic stewardship programs in the ICU: Insistence and persistence in the fight against resistance. A position statement from ESICM/ESCMID/WAAAR round table on multi-drug resistance. Intensive Care Med. 2018, 44, 189-196. [CrossRef]

49. Tabah, A.; Bassetti, M.; Kollef, M.H.; Zahar, J.R.; Paiva, J.A.; Timsit, J.F.; Roberts, J.A.; Schouten, J.; Giamarellou, H.; Rello, J.; et al. Antimicrobial de-escalation in critically ill patients: A position statement from a task force of the European Society of Intensive Care Medicine (ESICM) and European Society of Clinical Microbiology and Infectious Diseases (ESCMID) Critically Ill Patients Study Group (ESGCIP). Intensive Care Med. 2020, 46, 245-265. [CrossRef]

50. Weiss, E.; Zahar, J.R.; Garrouste-Orgeas, M.; Ruckly, S.; Essaied, W.; Schwebel, C.; Timsit, J.F. De-escalation of pivotal beta-lactam in ventilator-associated pneumonia does not impact outcome and marginally affects MDR acquisition. Intensive Care Med. 2016, 42, 2098-2100. [CrossRef] 
51. Leone, M.; Bechis, C.; Baumstarck, K.; Lefrant, J.Y.; Albanèse, J.; Jaber, S.; Lepape, A.; Constantin, J.M.; Papazian, L.; Bruder, N.; et al. De-escalation versus continuation of empirical antimicrobial treatment in severe sepsis: A multicenter non-blinded randomized noninferiority trial. Intensive Care Med. 2014, 40, 1399-1408. [CrossRef]

52. Montravers, P.; Tubach, F.; Lescot, T.; Veber, B.; Esposito-Farèse, M.; Seguin, P.; Paugam, C.; Lepape, A.; Meistelman, C.; Cousson, J.; et al. Short-course antibiotic therapy for critically ill patients treated for postoperative intra-abdominal infection: The DURAPOP randomised clinical trial. Intensive Care Med. 2018, 44, 300-310. [CrossRef] [PubMed]

53. Armand-Lefèvre, L.; Angebault, C.; Barbier, F.; Hamelet, E.; Defrance, G.; Ruppé, E.; Bronchard, R.; Lepeule, R.; Lucet, J.-C.; El Mniai, A.; et al. Emergence of imipenem-resistant gram-negative bacilli in intestinal flora of intensive care patients. Antimicrob. Agents Chemother. 2013, 57, 1488-1495. [CrossRef] [PubMed]

54. Woerther, P.L.; Lepeule, R.; Burdet, C.; Decousser, J.W.; Ruppé, É.; Barbier, F. Carbapenems and alternative $\beta$-lactams for the treatment of infections due to extended-spectrum $\beta$-lactamase-producing Enterobacteriaceae: What impact on intestinal colonisation resistance? Int. J. Antimicrob. Agents 2018, 52, 762-770. [CrossRef] [PubMed]

55. Carlier, M.; Roberts, J.A.; Stove, V.; Verstraete, A.G.; Lipman, J.; de Waele, J.J. A Simulation Study Reveals Lack of Pharmacokinetic/Pharmacodynamic Target Attainment in De-escalated Antibiotic Therapy in Critically Ill Patients. Antimicrob. Agents Chemother. 2015, 59, 4689-4694. [CrossRef]

56. Beganovic, M.; Cusumano, J.A.; Lopes, V.; LaPlante, K.L.; Caffrey, A.R. Comparative Effectiveness of Exclusive Exposure to Nafcillin or Oxacillin, Cefazolin, Piperacillin/Tazobactam, and Fluoroquinolones Among a National Cohort of Veterans with Methicillin-Susceptible Staphylococcus aureus Bloodstream Infection. Open Forum Infect. Dis. 2019, 6, ofz270. [CrossRef] 